IZA DP No. 6630

The Impact of Immigration on the Well-Being of Natives

Alpaslan Akay Amelie F. Constant

Corrado Giulietti

June 2012 


\title{
The Impact of Immigration on the Well-Being of Natives
}

\author{
Alpaslan Akay \\ IZA \\ Amelie F. Constant \\ DIWDC, George Washington University \\ and IZA \\ Corrado Giulietti \\ IZA \\ Discussion Paper No. 6630 \\ June 2012 \\ IZA \\ P.O. Box 7240 \\ 53072 Bonn \\ Germany \\ Phone: +49-228-3894-0 \\ Fax: +49-228-3894-180 \\ E-mail: iza@iza.org
}

Any opinions expressed here are those of the author(s) and not those of IZA. Research published in this series may include views on policy, but the institute itself takes no institutional policy positions.

The Institute for the Study of Labor (IZA) in Bonn is a local and virtual international research center and a place of communication between science, politics and business. IZA is an independent nonprofit organization supported by Deutsche Post Foundation. The center is associated with the University of Bonn and offers a stimulating research environment through its international network, workshops and conferences, data service, project support, research visits and doctoral program. IZA engages in (i) original and internationally competitive research in all fields of labor economics, (ii) development of policy concepts, and (iii) dissemination of research results and concepts to the interested public.

IZA Discussion Papers often represent preliminary work and are circulated to encourage discussion. Citation of such a paper should account for its provisional character. A revised version may be available directly from the author. 


\section{ABSTRACT}

\section{The Impact of Immigration on the Well-Being of Natives ${ }^{*}$}

This paper examines the effect of immigration directly on the overall utility of natives. To the best of our knowledge, this is the first paper to explore such nexus. Combining information from the German Socio-Economic Panel dataset with detailed local labour market characteristics for the period 1997 to 2007, we investigate how changes in the spatial concentration of immigrants affect the subjective well-being of the German-born population. Our results suggest the existence of a robust, positive effect of immigration on natives' wellbeing. The presence of confounding local labour market characteristics has a negligible impact on the estimates. Furthermore, we find substantial evidence that the effect of immigration on well-being is a function of the assimilation of immigrants in the region. The effect of immigration is higher in regions with an intermediate level of economic assimilation and is essentially zero in areas where immigrants are either least or fully economically integrated. We conduct robustness checks to address the potential endogeneity between subjective well-being and immigration. Our tests indicate that natives are not crowded out by immigrants, and that the sorting of immigrants to regions with higher SWB is weak. This suggests that our main findings are not driven or strongly influenced by reverse causality or selectivity.

JEL Classification: C90, J61, D63

Keywords: immigration, subjective well-being, assimilation

Corresponding author:

Alpaslan Akay

IZA

P.O. Box 7240

53072 Bonn

Germany

E-mail: akay@iza.org

\footnotetext{
The authors would like to thank the participants of the $8^{\text {th }}$ IZA Annual Migration Meeting in Washington and are grateful to Andrew Oswald for his valuable comments on an earlier draft of the paper.
} 


\section{Introduction}

There has been substantial concern about the impact of immigration on the welfare of natives (e.g., Borjas, 1994; Friedberg and Hunt, 1995; Card, 2005). Traditionally, studies analysing the impact of migration on natives have employed "objective" measures of welfare such as wages and employment (Borjas, 1994, 2003; Card, 1990, 2001; Butcher and Card, 1991; Dustmann et al., 2005; Ottaviano and Peri, 2012). More recently, part of the migration literature has also focused on the impact of migration on public spending and prices (Brücker et al., 2002; Dustmann et al., 2010). The objective of this paper is to examine the effect of immigration directly on the welfare of natives using the overall experienced "utility", as proxied by the subjectively-reported well-being. To our knowledge, this is the first paper which examines the impact of immigration by using subjectively-reported well-being, i.e., directly on the (experienced) utility of individuals.

At a broader level, objective measures are only partially capable of capturing most of the aspects of life which generate welfare or - as more precisely expressed by utilitarians such as Jeremy Bentham - pleasure and pain after an experience (Kahneman and Sugden, 2005). In recent years economists have started to focus on using broader measures of welfare rather than purely objective ones to proxy the utility of individuals (e.g., Deaton, 2008; Fleurbaey, 2009). As Stiglitz et al. (2009, p.41) state: "Quality of life is a broader concept than economic production and living standards. It includes the full range of factors that influences what we value in living, reaching beyond its material side." In order to capture the overall welfare of individuals, researchers have shifted towards the adoption of subjective well-being measures (SWB, "happiness" or "life satisfaction").

The number of economic studies that investigate the determinants of SWB has increased substantially in recent years (for an overview see, e.g., Dolan et al., 2008; Frey and Stutzer, 2002). The use of alternative welfare measures has also stimulated policy debates. For instance, in 2009 the French government convened a group of Nobel laureates including Amartya Sen and Joseph Stiglitz to create an index for the country's well-being that would replace the traditional GDP measure and 
include subjectively-reported well-being levels. Today this new branch of the economic literature goes beyond exploring the determinants of well-being, and allows the testing of hypotheses and analysis of various issues that could not have otherwise been achieved using a standard neoclassic economic approach. Arising from these results are the large disutility from being unemployed (Winkelmann and Winkelmann, 1998; Clark and Oswald, 1994; Clark, 2003), the fact that age and subjective well-being have a U-shaped relationship with a minimum around the age of 40 (Frey and Stutzer, 2002), that married people have higher subjective well-being than singles (Clark and Oswald, 1994), and that both absolute and relative income affect subjective well-being (Easterlin, 1995; Clark et al., 2008).

For a long time now, economists have been focusing on the labour market impact of immigrants on the natives' objective measures of "welfare" such as wages and employment. The typical approach is to correlate these measures with the rate of immigration across local labour markets. The empirical evidence to date is rather mixed. While Borjas (2003) finds negative effects of immigration on the wages of natives in the US, others find that the impact of immigration, if any, is negligible (Card, 1990, 2001). More recently, Ottaviano and Peri (2012) document immigration as having a positive effect on the wages of high-skilled natives, and a negative (but negligible) effect on low-skilled natives.

A longitudinal study in the UK finds minor impacts on unemployment, participation and wages - both economically and statistically (Dustmann et al., 2005). Conversely another study finds that immigrants and natives are complements in production, hence there is no negative wage effect on natives. However, they also find evidence that newly-arrived immigrants are substitutes in production with immigrants already residing in the UK (Manacorda et al., 2012). Analysing the impact of immigration on the employment rates of native Germans, Pischke and Velling (1997) find that immigration does not adversely impact natives' employment. More recently, D'Amuri et al. (2010) analyse both the wage and employment effects of immigration in West Germany and find that immigration has essentially no impact on natives' labour market outcomes, but has an adverse effect on previous immigrants as in the study of Manacorda et al. (2012). 
Another strand of the literature has explored the impact of immigration on other outcomes while still using objective measures of welfare. For example, Dustmann et al. (2010) analyse whether the immigration stemming from the EU enlargement toward Eastern European countries impacted UK public finances. They find that immigrants from the accession countries positively contributed to public finances, since they were found relatively more likely to be in work than natives, and less likely to access social benefits. Another branch of studies has started to explore the impact of immigration on natives' attitudes. For example Card et al. (2005) analyse data from the European Social Survey and conclude that while attitudes towards immigrants are partially shaped by economic factors, other aspects such as culture, and natives' social status are important in affecting the way immigration is perceived. Another example is Boeri (2010), who argues that opinions towards immigrants are affected by the business cycle.

The paper focuses on Germany, a decision based on several reasons. First, Germany is a high immigration country. Estimates by Eurostat report that 9.8 million individuals residing in Germany in 2010 were foreign-born (accounting for as much as $12 \%$ of total population). ${ }^{1}$ Second, we base our study on the German Socio-Economic Panel (GSEOP), which has the unique feature of being a highly representative dataset with longitudinal information on subjective well-being and identical questions posed to both natives and immigrants. Furthermore, GSOEP can be merged with data from the INKAR, a dataset containing local labour market characteristics such as GDP and unemployment rates. ${ }^{2}$ In addition, INKAR provides rich and reliable data on immigration stocks and flows at the local level, upon which our identification strategy hinges.

We estimate various hybrid equations where well-being is expressed as a function of the proportion of immigrants in the local labour market, controlling for individual socio-demographic characteristics, local labour market attributes, and regional and time fixed-effects. Our estimations provide robust evidence that a higher immigration rate in a local labour market generates a highly significant and positive effect on

\footnotetext{
${ }^{1}$ Source: http://epp.eurostat.ec.europa.eu/portal/page/portal/population/data/main_tables.

${ }^{2}$ INKAR is the acronym for Indikatoren und Karten zur Raumentwicklung.
} 
well-being of natives. In other words, natives experience welfare gain as immigration in the local labour market increases. For the purpose of comparison, we also conducted a similar analysis for the group of immigrants. We find some evidence that immigration positively affects the well-being of immigrants. The impact of immigration on well-being is found to vary substantially according to socio-demographic characteristics. In particular, the effect is larger for females, younger individuals, persons who are not married and those who are relatively less wealthy.

When we further control for local labor market characteristics such as unemployment rates and GDP we do not find any difference in the effect of immigration on well-being. However, after adding the immigrants' economic assimilation in the local labour market we stumble upon an interesting result. Specifically, not only is the effect of immigration on the well-being of natives a function of immigrants' economic assimilation, but it increases up to a certain "assimilation threshold" and decreases to effectively zero in those regions where assimilation is achieved, when the economic outcomes of immigrants fully converge with those of natives. Finally, we conduct various robustness checks to address potential endogeneity between immigration and well-being. We identify two potential sources of endogeneity. The first relates to the possibility that less happy natives move out from areas with higher immigration - which would create a spurious positive correlation between immigration and well-being. The second source of endogeneity has to do with the mobility of migrants between regions. If there is a substantial sorting of migrants into areas with higher well-being, issues of reverse causality might arise, i.e., the observed immigration rate could be a function of SWB. Our tests suggest that our main results are not driven or strongly influenced by reverse causality or selectivity.

The remainder of the paper is organized as follows: Section 2 summarizes the data used in this study and provides a detailed description of the local labor market attributes. Section 3 outlines the empirical strategy. The benchmark results of our analysis are presented in Section 4, while in Section 5 we examine the impact of local labor market characteristics. Section 6 explores the effect of immigrants' assimilation on the well-being of natives in detail. Section 7 provides additional results from robustness checks and from the detailed examination of the endogeneity 
issues. In Section 8 we conclude the paper with a brief discussion of our results.

\section{Data and summary statistics}

\subsection{Data and variable selection}

The empirical analysis of this paper is based on two distinct data sources. We combine a dataset extracted from the German Socio-Economic Panel dataset (GSOEP) with rich regional data from official statistics of Germany. The GSOEP has been extensively used in the SWB literature (e.g., Winkelmann and Winkelmann, 1998; Van Praag et al., 2003; Ferrer-i Carbonell and Frijters, 2004). This annual panel survey was first launched in West Germany in 1984, collecting data on 12,000 households which have been followed ever since. The sample has been extended over the years, most notably by including around 2,000 East German households in 1990 . From the GSOEP we extract a rich set of socio-economic variables at the individual level. In particular, we obtain information to construct the SWB variable. This is derived from the question "How satisfied are you at present with your life as a whole?", which allows responses on an ordinal scale from 0 to 10, where 0 stands for "completely dissatisfied" and 10 for "completely satisfied."

The second data source is the INKAR, from which we extract statistics for the 96 "regional policy regions" of Germany (henceforth, ROR). ${ }^{3}$ Since the GSOEP contains information on the ROR of residence of the individual, it is possible to match the microdata with the regional statistics. The advantages of using ROR level data are manifold. Firstly, RORs are well-defined spatial units, designated on the basis of economic attributes and commuting patterns (Knies and Spiess, 2007). This detailed geographical level allows the efficient capturing of the heterogeneity of German local labour markets. Furthermore, indicators are drawn from official statistics, which substantially attenuates measurement error issues. Our key regional variable is the proportion of immigrants in each ROR, namely the percentage of

\footnotetext{
${ }^{3}$ ROR stands for "RaumOrdnungsRegionen". The original number of RORs was 97 until July 2008. Since then, the RORs Chemnitz-Erzgebirge and Südwestsachsen were merged into the ROR Südsachsen. Details about this data are available at http://www.bbsr.bund.de/BBSR/DE/Veroeffentlichungen/INKAR/inkar_node.html.
} 
immigrants in the total resident population. In addition, we extract data on local unemployment rates (both for the total population and for immigrants) and GDP.

Since INKAR data is only available for the period 1997 to 2007, our analysis will be limited to this time period. Furthermore, we restrict the sample to individuals aged between 16 and 65. The final sample obtained by merging GSOEP and INKAR data consists of more than 160,000 individual-year observations.

\subsection{Regional patterns}

One of the key sources of variation for our analysis lies in the spatial distribution of immigrants across RORs. In this section we provide a detailed account of the regional variation in immigration patterns in Germany. The map in Figure 1 depicts average immigration rates over the period 1997-2007 for all RORs used in this study. Darker colors represent a higher immigration rate - defined as the proportion of foreign-born individuals in the region over its total population. ${ }^{4}$

There is a substantial variation in the immigration rate across regions, which also differs strikingly between the East and West of Germany. In West Germany immigration rates vary from a minimum of $1.5 \%$ to a maximum of $16.8 \%$. Although on the one hand it is possible to observe clusters of high and intermediate immigration rates, on the other hand contiguous RORs within the same Federal State exhibit diverse immigration incidences. This suggests that the definition of labour market based on Federal State would tend to underestimate the heterogenous immigration patterns across contiguous areas.

In order to provide preliminary evidence of the relationship of interest, the top panel of Figure 2 depicts the bivariate correlation between the immigration rate

\footnotetext{
${ }^{4}$ Immigration in Germany expanded during the 1960s and 1970s through the "guest workers" programmes stemming from bilateral agreements between Germany and partner countries, such as Greece, Italy, Spain and Turkey. After the termination of the guest worker programmes in 1973, immigration to guest workers regions continued through other channels such as family reunification. During the early 1990s, a relatively large wave of immigrants came under the asylum seeker and refugee status. During this time, many "ethnic Germans" also arrived in Germany, as well as many Russians, Poles and other Eastern Europeans. More recently, the enlargement of the European Union (EE) to Central and Eastern Europe countries did not generate a large increase of immigration, perhaps also due to the implementation of transitional rules (until May 2011), according to which Germany can still impose restrictions on the free movement of workers from the new Member States joining the EU.
} 
Figure 1: Immigration rate in the RORs

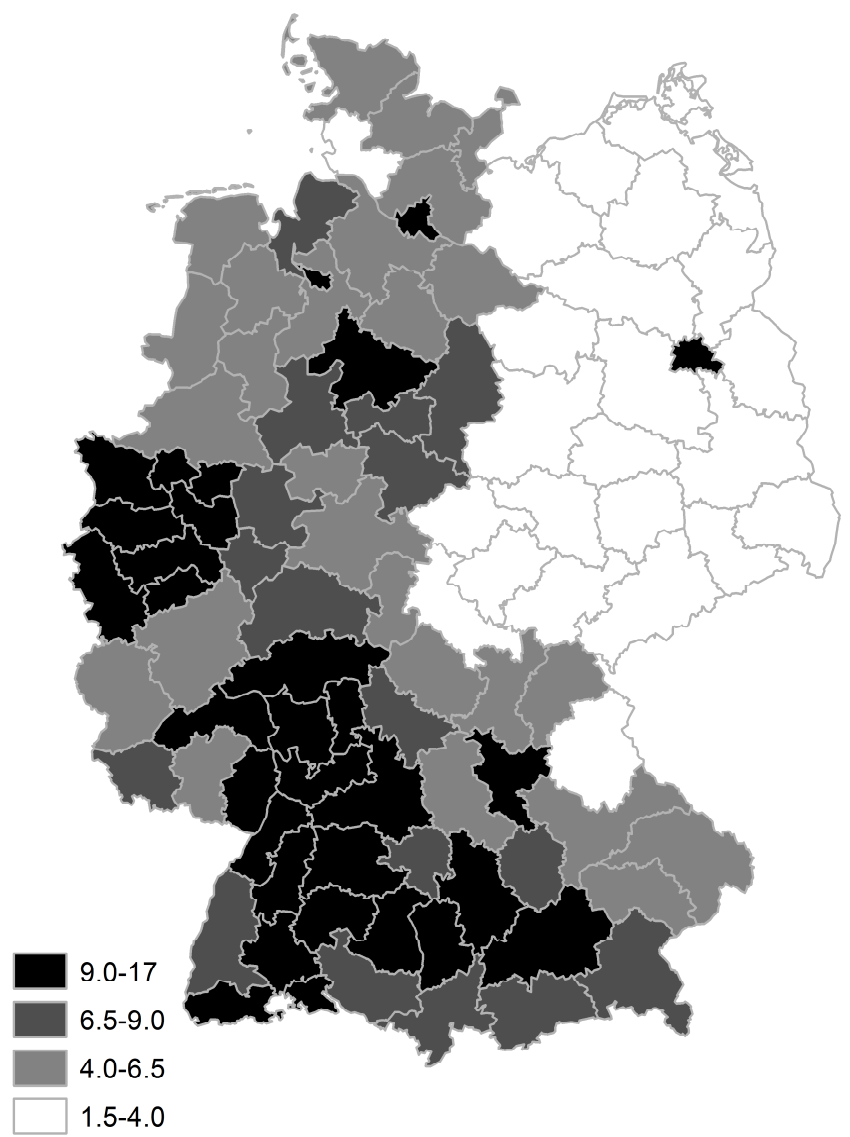

Source: INKAR 1997-2007. Digital boundaries from Raumordnungsregionen CCBKG/BBSR 2011 (http://www.bbsr.bund.de). Immigration rates refer to averages over time.

(IR) and SWB for both natives and immigrants. The figures refer to averages at the ROR level over time. Although the scatter plot is constructed using aggregated values, it reveals the existence of a positive relationship between the immigration rates and SWB, at least for natives. The pattern for immigrants also appears positive, but relatively noisy, especially at low level of immigration rates. This is due to the smaller sample size of this group in low immigration RORs. Indeed, it is necessary to account for many other factors which are potentially correlated with both SWB and immigration rate. For example, high immigration RORs are also relatively less deprived, as they exhibit low unemployment rates and high income in local GDP. In turn, these two economic factors are also major determinants of SWB. The econometric analysis outlined in the following section carefully addresses the potential confounding effects deriving from such regional heterogeneity. 
Figure 2: Regional characteristics
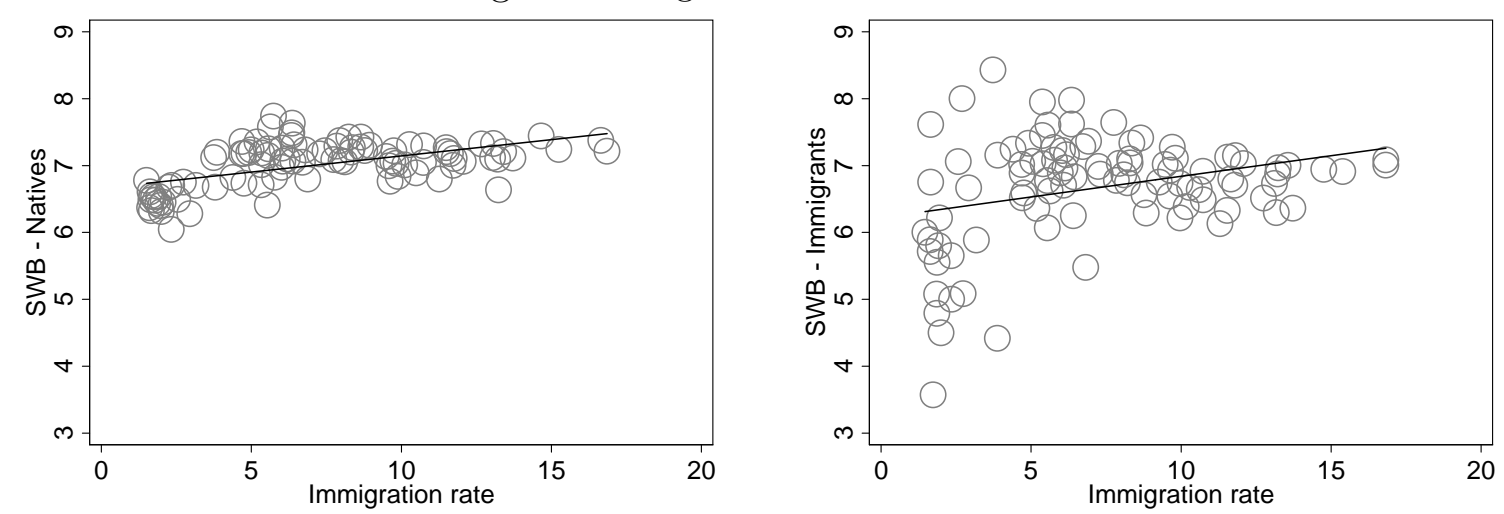

Source: the immigration rate is derived from INKAR 1997-2007; the subjective well-being (SWB) variable is obtained from GSOEP 1997-2007. The figures plot patterns for the 96 RORs.

\subsection{Summary statistics}

Table 1 presents the descriptive statistics of the variables used in the analysis. The statistics are reported separately for the groups of natives and immigrants. The sample is also decomposed into regions with high and low immigration (i.e., above and below the median immigration rates in the ROR). The natives in low immigration RORs report slightly lower levels of well-being than those in RORs with high immigration rates. Immigrants in low immigration regions exhibit higher levels of well-being than natives, while the opposite is true in high immigration RORs.

Across high and low immigration RORs, natives exhibit differences in few socioeconomic characteristics; their education level, household income and individual wages are slightly higher in high immigration RORs. On the contrary, immigrants in high immigration RORs are somewhat over-represented in the lowest education category, and exhibit lower individual wages. However, they also have marginally higher household income than immigrants in low immigration RORs. In summary, Table 1 reveals that levels of SWB vary across high and low immigration RORs for natives and immigrants; however, the characteristics of individuals are also different. It is important to recall from Figure 2 that macroeconomic conditions are substantially heterogeneous across high and low immigration RORs. The empirical 
strategy developed in the next section shows how we take into account of the substantial heterogeneity across individuals and regions.

Table 1: Summary statistics - individual characteristics

\begin{tabular}{|c|c|c|c|c|c|c|c|c|}
\hline \multirow[b]{3}{*}{ Characteristics } & \multicolumn{4}{|c|}{ Low immigration regions (RORs) } & \multicolumn{4}{|c|}{ "High immigration regions (RORs) } \\
\hline & \multicolumn{2}{|c|}{ Natives } & \multicolumn{2}{|c|}{ Immigrants } & \multicolumn{2}{|c|}{ Natives } & \multicolumn{2}{|c|}{ Immigrants } \\
\hline & mean & s.dev & mean & s.dev & mean & s.dev & mean & s.dev \\
\hline SWB & 6.819 & $(1.777)$ & 7.031 & $(1.773)$ & 7.118 & $(1.717)$ & 6.825 & $(1.789)$ \\
\hline \multicolumn{9}{|l|}{ Demographics } \\
\hline Age & 42.033 & $(13.141)$ & 41.921 & $(12.501)$ & 42.113 & $(12.854)$ & 42.735 & $(12.315)$ \\
\hline Males (\%) & 0.489 & $(0.500)$ & 0.484 & $(0.500)$ & 0.486 & $(0.500)$ & 0.491 & $(0.500)$ \\
\hline East Germany (\%) & 0.490 & $(0.500)$ & 0.051 & $(0.221)$ & 0.052 & $(0.222)$ & 0.005 & $(0.074)$ \\
\hline \multicolumn{9}{|l|}{ Completed education } \\
\hline less than 10 yrs & 0.079 & $(0.269)$ & 0.298 & $(0.457)$ & 0.096 & $(0.294)$ & 0.407 & $(0.491)$ \\
\hline $10 \mathrm{yrs}$ & 0.251 & $(0.434)$ & 0.255 & $(0.436)$ & 0.255 & $(0.436)$ & 0.206 & $(0.405)$ \\
\hline 11 yrs & 0.274 & $(0.446)$ & 0.189 & $(0.391)$ & 0.216 & $(0.412)$ & 0.141 & $(0.349)$ \\
\hline 12 yrs & 0.115 & $(0.318)$ & 0.088 & $(0.284)$ & 0.094 & $(0.291)$ & 0.071 & $(0.257)$ \\
\hline 13 or above yrs & 0.281 & $(0.450)$ & 0.170 & $(0.375)$ & 0.340 & $(0.474)$ & 0.173 & $(0.379)$ \\
\hline \multicolumn{9}{|l|}{ Household and children } \\
\hline Household size (log) & 0.975 & $(0.454)$ & 1.159 & $(0.467)$ & 0.936 & $(0.486)$ & 1.110 & $(0.467)$ \\
\hline No children (\%) & 0.616 & $(0.486)$ & 0.446 & $(0.497)$ & 0.616 & $(0.486)$ & 0.487 & $(0.500)$ \\
\hline One child (\%) & 0.207 & $(0.405)$ & 0.235 & $(0.424)$ & 0.191 & $(0.393)$ & 0.223 & $(0.416)$ \\
\hline Two children (\%) & 0.137 & $(0.344)$ & 0.187 & $(0.390)$ & 0.146 & $(0.353)$ & 0.197 & $(0.398)$ \\
\hline Three or more $(\%)$ & 0.040 & $(0.196)$ & 0.132 & $(0.339)$ & 0.047 & $(0.212)$ & 0.093 & $(0.291)$ \\
\hline \multicolumn{9}{|l|}{ Marital status } \\
\hline Married (\%) & 0.613 & $(0.487)$ & 0.784 & $(0.411)$ & 0.604 & $(0.489)$ & 0.769 & $(0.422)$ \\
\hline Separated (\%) & 0.018 & $(0.134)$ & 0.018 & $(0.131)$ & 0.023 & $(0.149)$ & 0.026 & $(0.160)$ \\
\hline Single (\%) & 0.269 & $(0.444)$ & 0.126 & $(0.332)$ & 0.273 & $(0.446)$ & 0.120 & $(0.325)$ \\
\hline Divorced (\%) & 0.076 & $(0.265)$ & 0.053 & $(0.225)$ & 0.081 & $(0.273)$ & 0.058 & $(0.234)$ \\
\hline Widowed (\%) & 0.024 & $(0.152)$ & 0.015 & $(0.122)$ & 0.020 & $(0.138)$ & 0.022 & $(0.147)$ \\
\hline Spouse abroad (\%) & 0.000 & $(0.000)$ & 0.003 & $(0.058)$ & 0.000 & $(0.014)$ & 0.005 & $(0.068)$ \\
\hline \multicolumn{9}{|l|}{ Health } \\
\hline No Answer/ NA (\%) & 0.002 & $(0.039)$ & 0.001 & $(0.031)$ & 0.001 & $(0.035)$ & 0.001 & $(0.031)$ \\
\hline Very good (\%) & 0.093 & $(0.290)$ & 0.106 & $(0.308)$ & 0.114 & $(0.318)$ & 0.104 & $(0.305)$ \\
\hline Good (\%) & 0.454 & $(0.498)$ & 0.425 & $(0.494)$ & 0.459 & $(0.498)$ & 0.430 & $(0.495)$ \\
\hline Satisfactory (\%) & 0.323 & $(0.468)$ & 0.309 & $(0.462)$ & 0.297 & $(0.457)$ & 0.291 & $(0.454)$ \\
\hline Poor $(\%)$ & 0.105 & $(0.306)$ & 0.131 & $(0.338)$ & 0.105 & $(0.307)$ & 0.136 & $(0.343)$ \\
\hline $\operatorname{Bad}(\%)$ & 0.024 & $(0.152)$ & 0.028 & $(0.164)$ & 0.023 & $(0.150)$ & 0.038 & $(0.190)$ \\
\hline \multicolumn{9}{|l|}{ Labour market } \\
\hline Employed (\%) & 0.687 & $(0.464)$ & 0.635 & $(0.482)$ & 0.719 & $(0.449)$ & 0.616 & $(0.486)$ \\
\hline Not in labour force (\%) & 0.201 & $(0.401)$ & 0.233 & $(0.423)$ & 0.207 & $(0.405)$ & 0.266 & $(0.442)$ \\
\hline Retired (\%) & 0.005 & $(0.068)$ & 0.003 & $(0.055)$ & 0.004 & $(0.064)$ & 0.004 & $(0.062)$ \\
\hline In school or training $(\%)$ & 0.025 & $(0.156)$ & 0.025 & $(0.157)$ & 0.027 & $(0.162)$ & 0.017 & $(0.128)$ \\
\hline Unemployed (\%) & 0.082 & $(0.275)$ & 0.104 & $(0.305)$ & 0.043 & $(0.202)$ & 0.097 & $(0.296)$ \\
\hline Self-employed (\%) & 0.064 & $(0.245)$ & 0.031 & $(0.174)$ & 0.076 & $(0.265)$ & 0.045 & $(0.207)$ \\
\hline Wages (log) & 7.519 & $(4.115)$ & 6.841 & $(4.392)$ & 7.894 & $(4.101)$ & 6.758 & $(4.567)$ \\
\hline Hours worked (log) & 2.412 & $(1.734)$ & 2.175 & $(1.749)$ & 2.498 & $(1.678)$ & 2.125 & $(1.769)$ \\
\hline Household income (log) & 7.963 & $(0.596)$ & 7.896 & $(0.568)$ & 8.104 & $(0.607)$ & 7.971 & $(0.571)$ \\
\hline $\mathrm{N}$ & \multicolumn{2}{|c|}{72,359} & \multicolumn{2}{|c|}{6,156} & \multicolumn{2}{|c|}{66,681} & \multicolumn{2}{|c|}{16,384} \\
\hline
\end{tabular}

Source: own computations from GSOEP 1997-2007. 


\section{Econometric specifications}

Our dependent variable is measured on an ordinal scale from zero to ten, and the appropriate econometric model is an ordered probit. Hence, our default specification is the ordered probit model in which well-being is considered to be latent (unobserved):

$$
\begin{aligned}
S W B_{i t}^{*} & =\beta I R_{r t}+\mathbf{X}_{i t}^{\prime} \boldsymbol{\gamma}+\mathbf{Z}_{r t}^{\prime} \boldsymbol{\lambda}+\epsilon_{i t}, \\
\epsilon_{i t} & =\alpha_{i}+\delta_{r}+\theta_{t}+\varepsilon_{i t}
\end{aligned}
$$

where $S W B^{*}$ captures the latent well-being or utility of an individual $i$ at time $t$. The key parameter to identify is $\beta$, which denotes how the immigration rate $(I R)$ in region $r$ at a certain time $t$ affects the SWB of individuals. The matrix $\mathbf{X}$ comprises individual socio-demographic and economic characteristics such as age, marital status and income. The matrix $\mathbf{Z}$ includes time-varying labour market characteristics, such as unemployment rate and GDP per capita in each region $r$ at a given time $t ; \boldsymbol{\gamma}$ and $\boldsymbol{\lambda}$ are the corresponding vectors of parameters to be estimated.

The error term $\epsilon$ and its components are represented in equation (2): $\alpha$ captures individual unobservable heterogeneity; $\delta$ encapsulates region-specific, time-invariant attributes, and $\theta$ represents time dummies; finally, $\varepsilon$ is an error term which is assumed to be normally distributed with a unit variance due to identification in the ordered probit specifications. While the econometric specification is presented as an ordered probit model due to the metric structure of the dependent variable, in this paper we estimate various alternative specifications to examine the effect of the immigration on SWB, including linear models. In the case of the sample under scrutiny, linear regression provides qualitatively similar results, and hence this method will be used (Ferrer-i Carbonell and Frijters, 2004). The advantages of using a linear specification are that it allows an easier interpretation of the parameter estimates and it enables to control for individual unobservable characteristics in simpler fashion.

As discussed by Boyce (2010), the role of unobserved personal characteristics, such as personality traits, is crucial with a subjective dependent variable. If these 
factors - as captured by the term $\alpha$ in equation (2) - are correlated with other regressors $\left(E\left(\epsilon_{i t}, x_{i t}\right) \neq 0\right)$, then a fixed effects specification would be preferred. However, in our specification, a fixed-effects estimator would also render some disadvantages. For example, estimating equation (1) by including both fixed-region and fixed-individual effects would essentially correspond to estimating the impact of immigration on individuals who actually change their region of residence (internal migrants), which is not the primary objective of interest. Furthermore, when comparing the impact of migration on SWB between natives and immigrants, estimates would not be directly comparable, as certain time-invariant factors would not be identified (e.g., years since migration, or arrival cohorts in the case of migrants). To address these issues whilst allowing individual heterogeneity to be correlated with observable individual covariates, equations (1) and (2) will be estimated using a correlated random-effects model (also known as quasi-fixed-effects $(Q F E)$, see Chamberlain, 1984). This corresponds to a random-effects model augmented with means of time-variant individual characteristics (e.g., household size, net income and weekly working hours). While the $Q F E$ will act as the benchmark specification, we will additionally provide estimates of OLS, random-effects and fixed-effects models for comparison purposes.

\section{Results}

\subsection{Effect of migration on the well-being of natives: bench- mark results}

In this section, we test for the effect of immigration rates on the SWB of natives and immigrants. This is achieved by estimating equations (1) and (2). In Table 2 we report the results of the estimation using alternative specifications. Although the table only reports the coefficients of interest (namely the $\beta$ of equation (1)), it is important to first discuss how the estimates of our model compare with existing literature. The full estimation of the model - which includes all socio-economic characteristics listed in Table 1 - is reported in the Appendix. For the aims of 
this section, it is important to briefly mention that our results are consistent with previous literature concerning the study of SWB in Germany (Ferrer-i Carbonell, 2005; Winkelmann and Winkelmann, 1998). Our results show that having more children and being married are positively correlated with well-being; the same applies for possessing more years of education/training, being healthy and having a higher income. As established in the SWB literature, being unemployed is negatively associated with life satisfaction. The pattern of SWB over the life cycle exhibits the "classic" U-shaped behaviour, meaning that well-being decreases into an age "dip" until the age of $40-45$, and then increases again (see Frey and Stutzer, 2002; Dolan et al., 2008).

In reference to the parameters of interest, Table 2 reports benchmark results separately for the groups of natives, immigrants, and of the two groups together. The rationale of these regressions is to estimate the impact of immigration on SWB once observable and unobservable individual characteristics have been taken into account. At this stage we present results by omitting other regional factors such as regional GDP and unemployment rates. We commence - for comparison purposes with an ordinary least squares (OLS) specification. The results are reported in the first column of Table 2. The parameter estimate suggests that a higher immigration rate in the ROR is positively and significantly correlated with the SWB level of both natives and immigrants. The size of the coefficient is somewhat smaller for natives (0.043) than immigrants (0.078), while the estimate for both groups falls in between (0.052). These estimates imply that, ceteris paribus, an increase in one standard deviation in the ROR immigration rate is associated with an increase of 0.1 standard deviations in natives' SWB and of 0.4 standard deviations in the SWB of immigrants. ${ }^{5}$

The second column of Table 2 presents results from the ordered probit (OP) specification. The only difference from the first column is that the dependent variable is considered to be an ordered (rather than continuous) outcome. The ordered probit

\footnotetext{
${ }^{5}$ We also estimated OLS specifications in which observations are clustered at the ROR level. As expected, the estimated standard errors are larger, generating less precise estimates. Yet, the pattern of the results is remarkably similar to the one in the first column. Our preferred model is based on a QFE specification where observations are clustered at the individual level.
} 
Table 2: Immigration and SWB - benchmark results

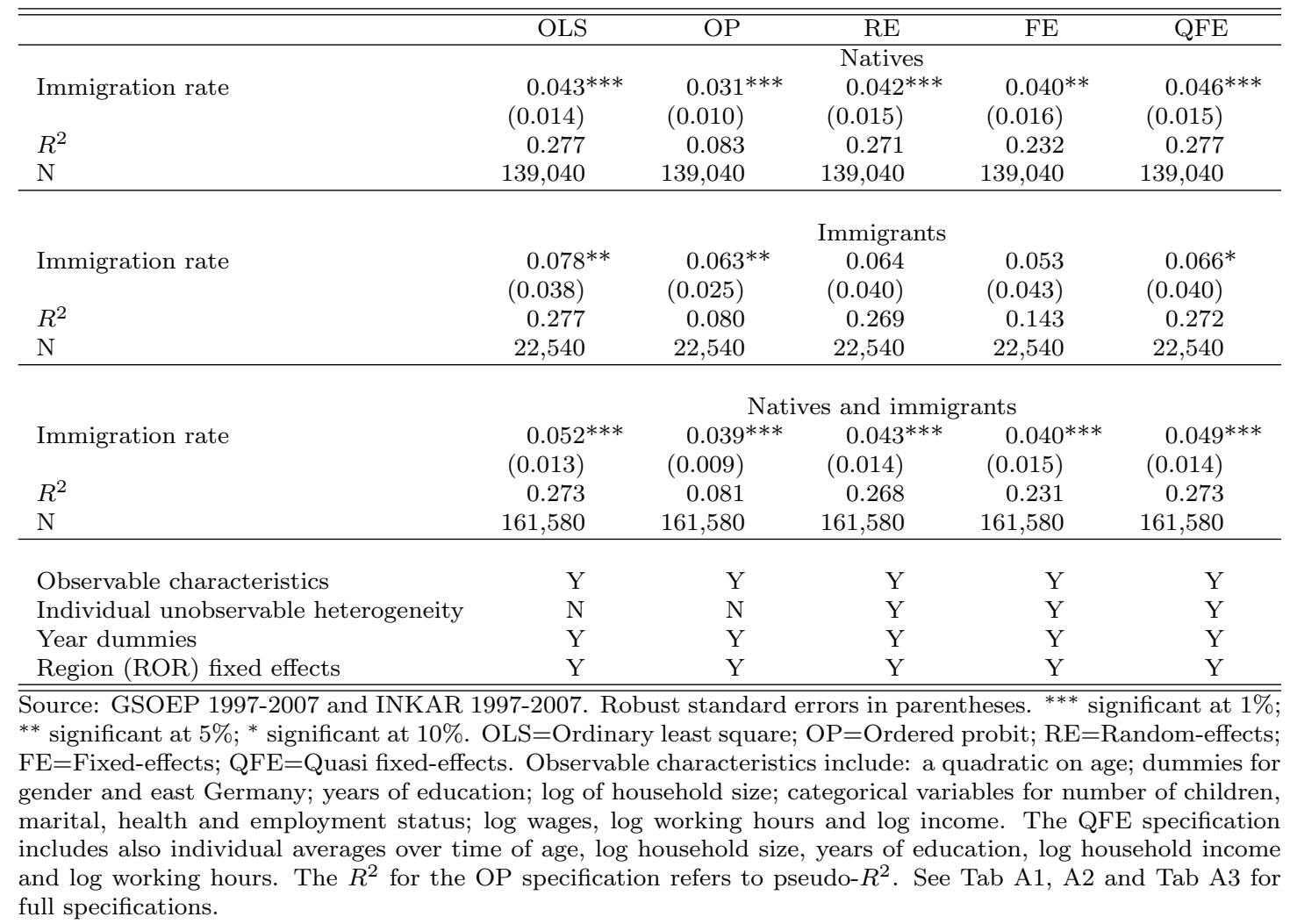

estimates are somewhat smaller than the OLS - in fact the magnitude of parameter estimates obtained from these two specifications is only partially comparable. What is relevant is that the pattern of the results does not change, namely there is an economically and statistically significant positive effect of the immigration rate on the SWB of natives and immigrants.

The presence of unobservable individual heterogeneity is addressed by estimating random- and fixed-effects (RE and FE) models in the third and fourth columns of Table 2, respectively. Interestingly, in both cases the size of the estimates for natives is very close to the OLS (which does not account for unobserved individual effects). For immigrants, even though the pattern of results is generally similar, the estimates are somewhat imprecise (the $p$-values are very close to conventional statistical significance levels in the case of random effects (0.105), but not in the case of the fixed-effect model (0.219)). The fact that the estimates across RE and FE models are qualitatively similar is confirmed by performing an Hausman test 
- the results of the test strongly reject the hypothesis that a systematic difference exists between the two models. ${ }^{6}$

The fifth column in Table 2 presents the results for our preferred specification the quasi fixed-effect model $(Q F E)$. This estimation strategy offers the advantage of allowing individual unobservable and observable characteristics to be correlated. Moreover, contrary to the fixed-effects specification it does not "wipe out" important time-invariant characteristics (such as gender or years since immigration for immigrants) or other factors that are likely to be constant for the majority of the population (for example, the ROR of residence). The QFE specification is largely similar to the random effects model in the third column, except that average individual characteristics over time are added as covariates. These include individuals' means of age, household size, education, log household income and log working hours. The estimates of the QFE specification are very similar to those of the RE model, though for immigrants they are slightly more precise.

\subsection{Which groups are affected? Results by socio-demographic characteristics}

In Table 3, we present the estimation results of equation (2) by sub-setting the data along several observable characteristics of individuals. This allows us to examine weather there is a heterogenous effect of immigration on SWB across different groups. The dimensions considered are gender, age, marital and employment status, education, and income level. All estimations are carried out using QFE specification. $^{7}$

Results reveal that the effect of immigration rate on SWB is economically and statistically stronger for females. This pattern is consistent across both natives and immigrants. For native females, the point estimate is somewhat smaller than for immigrant females (0.064 vs. 0.099). Table 3 exhibits an interesting pattern by age: the impact of immigration on SWB is positive for all three age groups considered

\footnotetext{
${ }^{6}$ The chi-squared values of the Hausman test are 2,664 for natives; 404 for immigrants and 2,892 for the two groups together.

${ }^{7}$ The results from the other model specifications can be provided by the authors upon request.
} 
Table 3: Estimates by observable characteristics

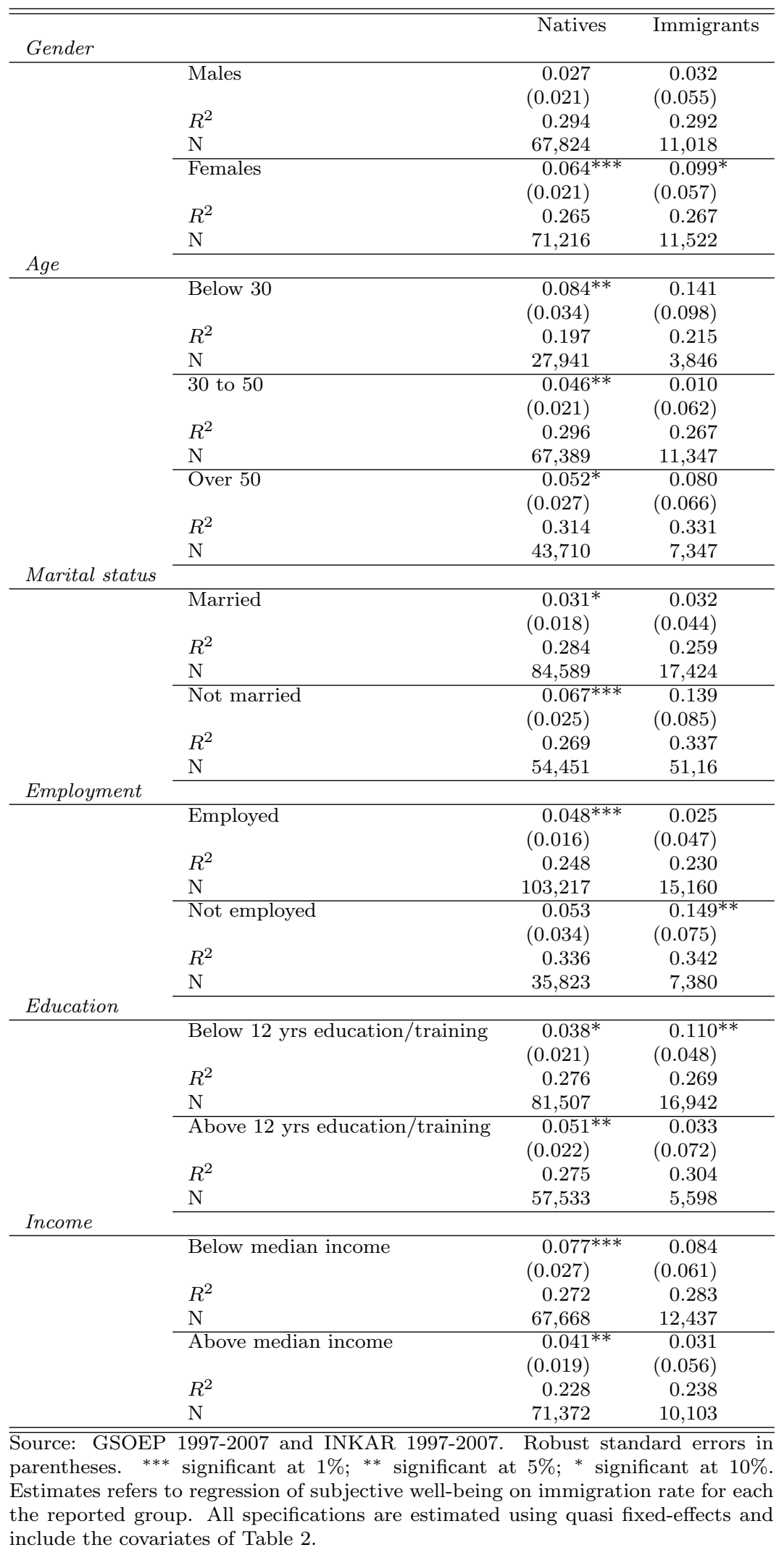


(i.e., below 30 years, between 31 and 50 and over 50 years). However, the estimated coefficient is highest for the younger group, decreases for the "prime-age" group and increases slightly for the group over 50. The same "U-shaped" pattern is observed for the immigrants, albeit with a rather low precision of the estimated parameters.

In regards to marital status, the impact of immigration on the SWB of natives who are not married is more than double of those who are married. The same finding emerges in the case of immigrants, however yet again the results are not statistically robust according to usual significance levels. Results by employment status are also interesting. In general, the estimated coefficient is larger for individuals who are not employed. Nevertheless, the estimates for the unemployed natives are somewhat imprecise. For immigrants, the estimate for the group of employed is essentially zero; on the other hand, the effect of immigration on the group not in employment is large and statistically robust.

A different pattern emerges across the groups of natives and immigrants in the case of education. The effect of immigration on SWB is somewhat larger for natives who have more years of education. By contrast, for immigrants, the effect appears to be concentrated on the group with less than 12 years of education/training; for more educated immigrants, the effect is very small and statistically insignificant. The last panel in Table 3 presents the results from the specification containing individuals with household income above and below the median. For individuals with lower income, the impact of immigration on SWB is larger than for individuals who report higher income. This is true for both natives and immigrants although results are statistically significant only in the case of natives.

\section{Where is this result coming from? The effect of the local labour market}

The benchmark results in Table 2 suggest that natives' and immigrants' well-being increases in concurrence with immigration in the ROR. Yet these specifications do not consider the confounding role that regional characteristics might exert on both immigration and well-being. Although we control for time-invariant regional char- 
acteristics in all our specifications - by introducing ROR dummies - the presence of time/region specific shocks could further affect the causal interpretation of our estimates. In this section, we present estimates of models in which we control for time-varying characteristics in the RORs, namely the regional GDP and the local unemployment rate. For example, if a ROR is characterised by high unemployment, natives and migrants may compete for the same jobs, potentially generating welfare loss among either or both groups. If the effect of these regional variables is particularly strong, the estimated impact found in Table 2 is likely the by-product of the confounding effect of local characteristics other than immigration. Another important issue is that the structure of the local labour market may also influence the sorting of immigrants into the regions. We will consider this issue separately and provide a full account in Section 7.

To mitigate the potential omitted variables bias induced by confounding factors at the ROR level, we test the sensitivity of our results to adding time-variant ROR characteristics in equation (2). These additional variables are the aggregate unemployment rate, immigrant-specific unemployment rate and GDP per capita. Table 4 contains $Q F E$ estimates of the same model as in the fifth column of Table 2, augmented by these regional controls. Controlling for the aggregate unemployment rate does not substantially impact the effect of immigration on natives' SWB; for immigrants, estimates are slightly smaller and not statistically significant at conventional levels. Furthermore, in general the estimated effect of the unemployment variable on SWB is insignificant. This does not imply that unemployment does not influence individuals' well-being. Rather, it means that changes in unemployment rates over time are not strongly correlated with changes in SWB. One explanation is that the presence of ROR fixed-effect is likely to have absorbed most of the negative influence of unemployment.

Interesting results emerge when we add GDP per capita to the specifications. Estimates for the impact of immigration on SWB are larger for both natives and immigrants. However, GDP is found to be negatively correlated with the individuals' subjective well-being. While at first sight this appears to be a puzzling result, two remarks are necessary: first, as pointed out in the case of unemployment, the 
Table 4: The influence of local labour market characteristics

\begin{tabular}{|c|c|c|c|c|c|c|}
\hline \multirow[b]{2}{*}{ Immigration rate } & \multicolumn{6}{|c|}{ 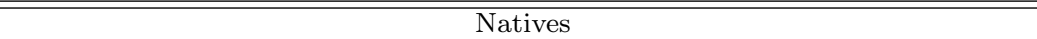 } \\
\hline & $\begin{array}{c}0.043^{* * *} \\
(0.016)\end{array}$ & $\begin{array}{c}0.054^{* * *} \\
(0.016)\end{array}$ & $\begin{array}{c}0.042^{* *} \\
(0.016)\end{array}$ & $\begin{array}{l}0.049^{* * *} \\
(0.018)\end{array}$ & $\begin{array}{c}0.048^{* * * *} \\
(0.018)\end{array}$ & $\begin{array}{c}0.048^{* * *} \\
(0.018)\end{array}$ \\
\hline Unemployment rate & $\begin{array}{r}0.003 \\
(0.006)\end{array}$ & & & $\begin{array}{l}-0.001 \\
(0.006)\end{array}$ & & $\begin{array}{r}-0.003 \\
(0.008)\end{array}$ \\
\hline Log GDP per capita & & $\begin{array}{l}-0.573^{* * *} \\
(0.175)\end{array}$ & & $\begin{array}{l}-0.466^{* *} \\
(0.189)\end{array}$ & $\begin{array}{l}-0.484^{* * *} \\
(0.188)\end{array}$ & $\begin{array}{l}-0.503^{* * *} \\
(0.193)\end{array}$ \\
\hline Immigrant unemployment rate & & & $\begin{array}{r}0.002 \\
(0.005)\end{array}$ & & $\begin{array}{r}0.000 \\
(0.005)\end{array}$ & $\begin{array}{r}0.002 \\
(0.007)\end{array}$ \\
\hline $\begin{array}{l}R^{2} \\
\mathrm{~N}\end{array}$ & $\begin{array}{r}0.279 \\
130,510\end{array}$ & $\begin{array}{r}0.276 \\
126,193\end{array}$ & $\begin{array}{r}0.279 \\
130,013\end{array}$ & $\begin{array}{r}0.278 \\
117,663\end{array}$ & $\begin{array}{r}0.277 \\
117,166\end{array}$ & $\begin{array}{r}0.277 \\
117,166\end{array}$ \\
\hline & & & Imm & rrants & & \\
\hline Immigration rate & $\begin{array}{r}0.050 \\
(0.045)\end{array}$ & $\begin{array}{c}0.083^{* *} \\
(0.042)\end{array}$ & $\begin{array}{r}0.056 \\
(0.045)\end{array}$ & $\begin{array}{r}0.073 \\
(0.048)\end{array}$ & $\begin{array}{r}0.077 \\
(0.049)\end{array}$ & $0.105^{* *}$ \\
\hline Unemployment rate & $\begin{array}{l}-0.023 \\
(0.021)\end{array}$ & & & $\begin{array}{c}-0.036 \\
(0.022)\end{array}$ & & $\begin{array}{l}-0.095^{* *} \\
(0.040)\end{array}$ \\
\hline Log GDP per capita & & $\begin{array}{r}-0.235 \\
(0.510)\end{array}$ & & $\begin{array}{l}-0.615 \\
(0.570)\end{array}$ & $\begin{array}{r}-0.500 \\
(0.574)\end{array}$ & $\begin{array}{r}-0.801 \\
(0.575)\end{array}$ \\
\hline Immigrant unemployment rate & & & $\begin{array}{r}0.005 \\
(0.016)\end{array}$ & & $\begin{array}{r}0.003 \\
(0.018)\end{array}$ & $\begin{array}{l}0.062^{* *} \\
(0.032)\end{array}$ \\
\hline$R^{2}$ & 0.277 & 0.269 & 0.277 & 0.273 & 0.273 & 0.273 \\
\hline $\mathrm{N}$ & 20,413 & 20,922 & 20,412 & 18,795 & 18,794 & 18,794 \\
\hline
\end{tabular}

Source: GSOEP 1997-2007 and INKAR 1997-2007 (GDP available only 1997-2006). Robust standard errors in parentheses. ${ }^{* * *}$ significant at $1 \%$; ${ }^{* *}$ significant at $5 \%$; ${ }^{*}$ significant at $10 \%$. All specifications are estimated using quasi fixed-effects and include the covariates of Table 2.

presence of ROR dummies implies that the effect of changes in GDP on changes in SWB is what is estimated. Hence, the strong positive correlation between SWB and GDP exhibited in Figure 1 is once again likely to be absorbed by the presence of the ROR fixed-effect. Furthermore, a plausible explanation for this negative correlation can be attributed to the presence of "positional" or "relative" concerns with respect to income. ${ }^{8}$ Hence, the change in GDP in the ROR represents the change in the level of income that the individuals would like to achieve. As GDP in the region increases, the income position of the individual would decrease relative to the relevant others. It therefore becomes more difficult for individuals to reach the income level of the "reference" group, thereby generating disutility (Clark and Oswald, 1996; Ferrer-i Carbonell, 2005; Clark et al., 2008).

The results are robust to the introduction of the immigrant-specific unemployment rate. The estimated impact of immigration on SWB is positive and very much

\footnotetext{
${ }^{8}$ Findings from the subjective well-being literature suggest that utility is not only a function of the absolute income, but also of how an individual's income "positions" in relation to the income of others individuals (Clark and Oswald, 1996; Senik, 2004; Luttmer, 2005; Ferrer-i Carbonell, 2005; Clark et al., 2008).
} 
in line with the benchmark results for both natives and immigrants. When regional variables are combined in the model, most of the results are similar to the benchmark specification, with the only exception being when all three regional indicators are added to the model for immigrants. The estimated impact of immigration on the well-being of immigrants becomes larger and more significant. While the impact of the aggregate unemployment is negative and significant - meaning that adverse changes in the labour market negatively affect well-being - the estimated parameter of the immigrant-specific unemployment rate is positive and significant. This means that adverse changes in the employment status of immigrants have a positive impact on well-being. This counterintuitive result could be potentially explained once again by positional concerns and by emphasising that the reference category in the regression corresponds with employed individuals. As economic conditions in the ROR worsen, it becomes relatively easier for employed immigrant to achieve the economic status of the reference group. Another, perhaps more intuitive explanation, is that the large correlation between the total and immigrant-specific unemployment rates (0.41) produces estimates which have opposite sign. In the remainder of the analysis, our preferred specifications will only contain the aggregate unemployment rate and GDP per capita.

While the results above suggest that regional characteristics, on average, are supportive of the benchmark results in Table 2, it is possible that the impact of immigration varies according to different regional attributes. To explore this point, we estimate an alternative specification of equation (1) which includes an interaction between the immigration rate and regional characteristics. In practice, we estimate three specifications where each of the regional variables considered before - aggregate unemployment rate, GDP per capita and immigrant-specific unemployment rate - is divided into quartiles and interacted with the immigration rate in the ROR. ${ }^{9}$ We control for the interactions of regional characteristics and each quartiles. This implies that the four interactions in each model include the main effect of the immigration variable. The interactions are indicated in Table 5 by the terms

\footnotetext{
${ }^{9}$ Each quartile is derived by first constructing the ROR distribution of each regional attribute. This is obtained by averaging the values of unemployment and GDP over time.
} 
$I R \times Q 1, I R \times Q 2, I R \times Q 3$, and $I R \times Q 4$. Here $Q 1$ refers to regions with the lowest quartile of each indicator; $Q 2$ and $Q 3$ to the second and third quartile; $Q 4$ to the upper $25 \%$ of regions in terms of value of a given ROR indicator. The results from the interaction models confirm the robustness of the benchmark regression. The effect of the immigration rate on natives' well-being is stable in regions with different levels of unemployment. On the contrary, the estimated effect of immigration on well-being decreases in areas with higher GDP per capita. We observe a similar pattern for immigrants, although not all of the estimated interactions are statistically significant at the conventional levels.

Table 5: The influence of local labour market characteristics: interaction models

\begin{tabular}{ccccccc}
\hline \hline & \multicolumn{2}{c}{ Unemployment rate } & \multicolumn{2}{c}{ Per capita GDP } & \multicolumn{2}{c}{ Imm. unemployment rate } \\
& Natives & Immigrants & Natives & Immigrants & Natives & Immigrants \\
\hline IR x Q1 & $0.049^{* * *}$ & $0.088^{*}$ & $0.046^{* *}$ & $0.095^{*}$ & $0.049^{* * *}$ & 0.073 \\
& $(0.017)$ & $(0.047)$ & $(0.018)$ & $(0.051)$ & $(0.018)$ & $(0.049)$ \\
IR x Q2 & $0.049^{* * *}$ & $0.089^{*}$ & $0.045^{* *}$ & 0.077 & $0.050^{* * *}$ & 0.075 \\
& $(0.017)$ & $(0.047)$ & $(0.018)$ & $(0.048)$ & $(0.018)$ & $(0.049)$ \\
IR x Q3 & $0.050^{* * *}$ & $0.095^{* *}$ & $0.038^{* *}$ & 0.066 & $0.049^{* * *}$ & 0.078 \\
& $(0.018)$ & $(0.048)$ & $(0.018)$ & $(0.048)$ & $(0.018)$ & $(0.049)$ \\
IR x Q4 & $0.046^{* *}$ & 0.078 & $0.037^{* *}$ & 0.072 & $0.050^{* * *}$ & 0.076 \\
& $(0.018)$ & $(0.049)$ & $(0.018)$ & $(0.048)$ & $(0.019)$ & $(0.049)$ \\
$R^{2}$ & 117,663 & 18,795 & 117,663 & 18,795 & 117,166 & 18,794 \\
\hline \hline
\end{tabular}

Source: GSOEP 1997-2007 and INKAR 1997-2007 (GDP available only 1997-2006). Robust standard errors in parentheses. ${ }^{* * *}$ significant at $1 \%$; ${ }^{* *}$ significant at $5 \%{ }^{*}$ significant at $10 \%$. All specifications are estimated using quasi fixed-effects and include the covariates of Table 2. Estimates in each panel refer to interactions between immigration rates (IR) and categorical variables for the regional attributes, defined by the quartiles of their distributions (Q1, Q2, Q3, Q4).

\section{Who is affecting? Immigrants' assimilation and well-being of natives}

In this section we investigate another source of regional heterogeneity: the level of assimilation of immigrants in each ROR. The effect of immigration on natives' well-being might depend on the level to which immigrants are economically and culturally integrated in the region. We analyse this issue by first investigating how the estimated effect varies across regions with different levels of economic assimilation. This is achieved by using "objective measures" of assimilation based on the relative earnings (labour income) and employment probabilities of immigrants. We 
then consider "pseudo-objective" measures of assimilation which capture the level of cultural and social attachment of immigrants to the region of residence.

\subsection{Objective measures of assimilation}

Immigrants - much like natives - are clearly not a homogeneous group in terms of their skills. Some immigrants possess skills which are comparable and substitutable with those of natives; others which actually complement those possessed by natives. Since the labour market impact depends on this level of substitutability of skills, it might well be that the impact of immigration on natives' well-being (and of other immigrants) varies as a function of the level of competition in the labour market. Upon their arrival in the host country, immigrants may lack skills which are specific to the host country labour market, or possess skills which are not transferable. However, over time they acquire the necessary knowledge and skills - such as language - and can assimilate in the labour market meaning that their earnings reach parity with those of natives (Chiswick, 1978). To what extent immigrants' economic success plays a role in the well-being of natives is very much an empirical question. On the one hand, the economic integration of immigrants might produce more competitive pressures on natives; on the other hand, the fact that they are more assimilated in the labour market might also produce positive spillover for German-born individuals. Likewise, the assimilation of immigrants might also have ambiguous effects on the group of immigrants. As the labour market outcomes of immigrants converge with those of natives, indeed immigrants will gain in terms of well-being. However, this might also imply stronger competition pressures given that substitution among immigrants is generally stronger (Card, 2001; Manacorda et al., 2012).

To examine how immigrant economic integration influences our results, we construct two assimilation indicators - one for earnings assimilation and one for employment assimilation - and interact these measures with the immigration rate in the region. However, before presenting the results, we briefly outline how we constructed the assimilation indicators. The first step is to estimate earnings and employment assimilation models in line with Borjas $(1985,1999)$. We assume that the outcome $y$ (alternately earnings and employment probability) of each individual $i$ belonging 
to the group of natives $(n)$ or immigrants $(m)$ follows the data generating functions below:

$$
\begin{gathered}
\log \left(y_{i t}^{n}\right)=\mathbf{X}_{i t}^{\prime} \gamma^{n}+\sum_{h} \eta_{h}^{n} P_{h}^{n}+\alpha_{i}^{n}+\delta_{r}^{n}+\mathbf{Z}_{r t}^{\prime}+v_{i t}^{n} \\
\log \left(y_{i t}^{m}\right)=\mathbf{X}_{i t}^{\prime} \gamma^{m}+\pi^{m} y s m_{i t}^{m}+\sum_{k} \psi_{k} C_{k}+\sum_{h} \eta_{h}^{m} P_{h}^{m}+\alpha_{i}^{m}+\delta_{r}^{m}+\mathbf{Z}_{r t}^{\prime}+v_{i t}^{m}
\end{gathered}
$$

where $\mathbf{X}$ represents the same socio-economic characteristics as in equation (1); $\alpha$ is the unobserved individual effects; $\delta$ is the region of residence (ROR); and $v$ is the usual error term. The key variables are the years since migration variable $(y s m)$, which captures the assimilation effect, the cohort dummies $(C)$, which represent the arrival-cohort effect and the period-effects $(P) .{ }^{10}$ Years since migration and cohorteffects are not identified in the generating function of natives and are therefore omitted. Typically, the parameters $\pi, \psi$ and $\eta$ cannot be simultaneously identified because the three variables above are perfectly collinear (years since migration is equivalent to the difference between the period effect and the year of arrival). ${ }^{11}$

There are several approaches which are experimented in the literature to identify these three effects separately. One method is to estimate the equations for natives and immigrants jointly and achieve identification by imposing the restriction that the period-effects are the same for the two groups (i.e, $P_{h}^{n}=P_{h}^{m}, \forall h$ see Borjas, 1985). In this paper, we follow a "wage-curve" approach which imposes the restriction that period-effects have the same impact for natives and immigrants conditional on labour market characteristics (Barth et al., 2004). This is achieved by estimating an assimilation model which controls for regional characteristics (as represented by $\mathbf{Z}$ in the equation above). In addition, instead of using the year of entry in Germany,

\footnotetext{
${ }^{10}$ The model actually includes a quadratic on years since migration and age.

${ }^{11}$ It is crucial to control for all three aspects, albeit our purpose is to identify the assimilation effect. Cohort effects capture the fact that immigration in different periods occurs under different circumstances (both in Germany and the source country), and these unobserved characteristics might influence the labour market performance of both natives and immigrants. Furthermore, it is important to control for period effects, because the differential performance between natives and immigrants might vary with the business cycle.
} 
we group arrival cohorts into intervals of five years. This further reduces the issues of collinearity described above. ${ }^{12}$

Having estimated the parameters in equations (3) and (4), the second step is to predict the outcome variable $y$ (earnings and employment probabilities) for each individual $i$ and year $t$ for both groups of immigrants and natives. The third step consists of constructing a regional indicator of immigrant assimilation using the predicted output. ${ }^{13}$ The measures are constructed by calculating, in each region, the ratio between the average predicted earnings (or employment probability) of immigrants and the average predicted earnings (or employment probability) of natives:

$$
A_{r}=\frac{\sum_{i t} \hat{y}_{i r t}^{m} / M}{\sum_{i t} \hat{y}_{i r t}^{n} / N}
$$

where $\hat{y}$ represents the fitted values from equations (3) and (4) and $N$ and $M$ are the total numbers of natives and immigrants in the region, respectively. Values of $A_{r}$ close to (or above) 1 indicate that in a given ROR immigrants' outcomes converge with those of natives. Values below unity indicate that immigrants are less assimilated. We then determine quartiles from the distribution of $A_{r}$, that is $Q 1$ corresponds to RORs which are less assimilated, while $Q 4$ includes RORs where the outcomes of immigrants converge with those of natives.

We estimate a model similar to that in Table 5, whereby the immigration rate is interacted with the quartiles of the index $A_{r}$ for both earnings and employment probabilities. The interaction terms reveal whether the impact of immigration on the well-being of natives (and also other immigrants) depends on the extent to which immigrants are assimilated in the region. We present these results in Tables 6 and 7 where the models have been estimated using the earnings assimilation index and the employment assimilation index, respectively. The first column of each table contains the results for all individuals, with natives in the first panel and immigrants in the second panel. The other columns contain the results for each of the groups

\footnotetext{
${ }^{12}$ To test the robustness of the results, we experimented various models to identify the assimilation parameters. We found no substantial difference across different specifications employed.

${ }^{13}$ Both the models for earnings and employment are estimated using $Q F E$ specifications. We use linear probability model with $Q F E$ for the employment probability assimilation.
} 
considered in Table 3 .

A clear pattern emerges from the results of earnings assimilation in Table 6. For the group of natives, the effect of immigration on well-being does not distinctively differ from zero in RORs where immigrants are less assimilated. It then increases and "peaks" in RORs where immigrants are intermediately assimilated ( $Q 2$ and $Q 3)$, and decreases again to values which are essentially zero. The pattern differs only slightly for the groups of individuals with different socio-demographic characteristics. For individuals aged 30-50, the impact is positive and significant in correspondence with RORs which are less assimilated. In RORs where the earnings of immigrants converge with those of natives, the impact decreases to zero. We conduct the same analysis for the employment assimilation in Table 7 . The pattern of the results is remarkably similar to that we found in Table 6 . For natives, in the majority of the cases the effect of immigration on well-being follows a sort of "inverted-U" pattern, peaking in regions with intermediate levels of assimilation. For immigrants, the results are essentially similar to those in Table 6 .

The findings of the assimilation analysis provide further insight into which regions are more likely to be affected. Clearly, the impact of immigration on the natives' well-being is stronger in RORs in which immigrants are only partially assimilated. This result might also appear somewhat puzzling: why do natives become more satisfied with immigrants as assimilation increases, and why does the welfare gain experienced by natives disappear when immigrants achieve high levels of assimilation in the labour market? One potential explanation is that while the convergence of economic outcomes between immigrants and natives generates utility for the latter group (through spillover and complementarities), it could also generate more competition within the labour market - and hence disutility. Another potential interpretation is that when immigrants are completely assimilated, they may enter in the reference group of natives (since their economic outcomes are essentially the same), generating an "envy" effect. Although speculative, both explanations are compatible with the "decline" of the effect observed in more integrated regions. In the following sub-section, we will explore whether similar results hold when considering measures of assimilation which are not strictly economic. 


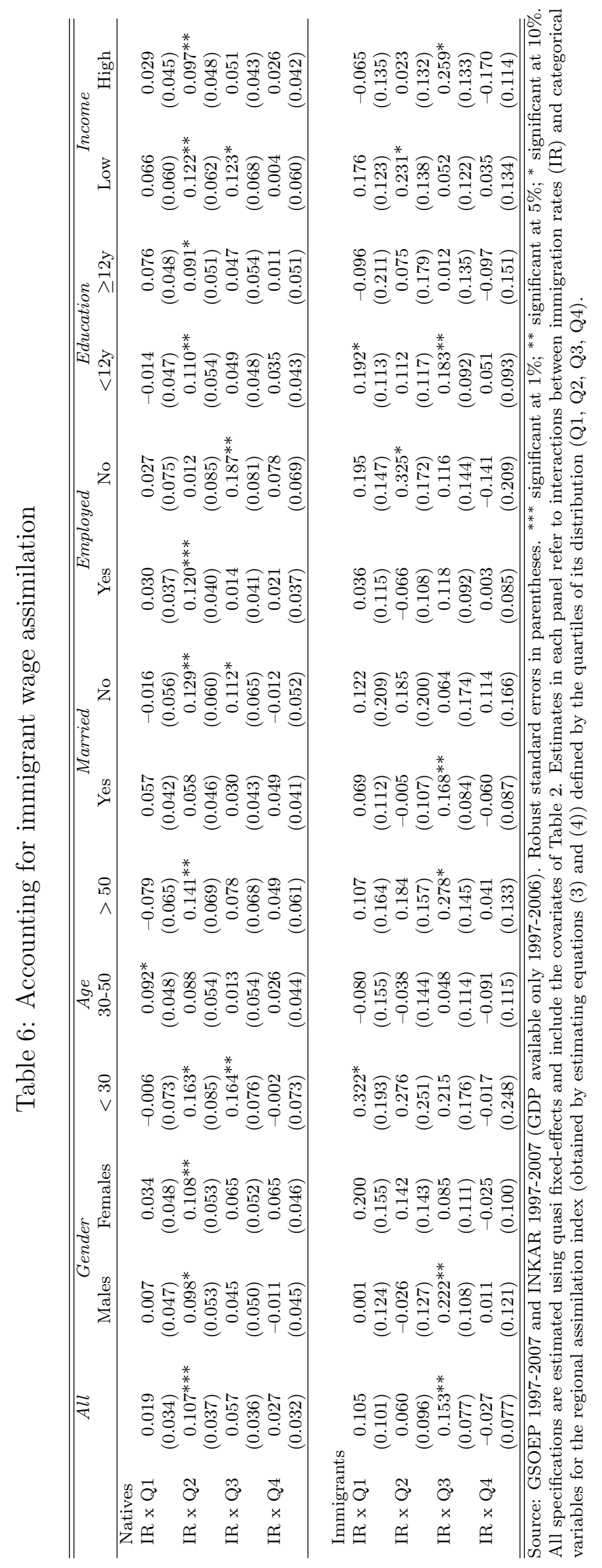




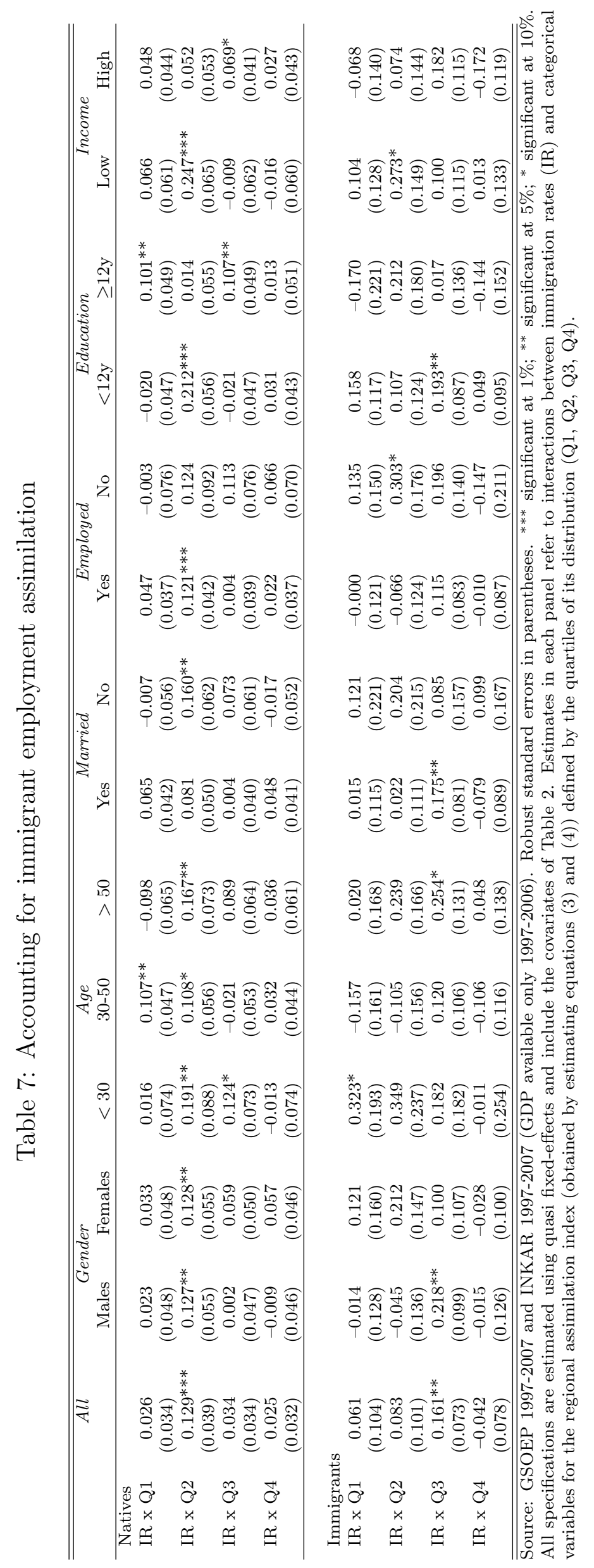




\subsection{Pseudo-objective and subjective measures of assimila- tion}

Although regions exhibit different levels of economic assimilation, they might also differ depending on the degree of the social and cultural integration of immigrants. As a consequence, the impact of immigration on well-being might vary depending on how immigrants integrate into the host society. To explore this point, we perform a similar analysis to that in Tables 6 and 7, using subjective indicators of integration. In particular, we construct three measures based on information from the GSOEP: one concerning "German identity" and two relating to language ability. ${ }^{14}$ The measure of identity is constructed using information from the questionnaire: "Feeling like a German", which allows five possible answers: 1) Completely, 2) Mostly, 3) In some respects, 4) Barely and 5) Not at all. We define a dichotomous variable which is equal to 1 for those individuals reporting values above the median (which is the category "In some respects") and is equal to 0 for those who feel "Barely" or "Not at all" German. We then calculate the regional mean of this indicator, that is, aggregating the values over time and across individuals in the same ROR. We hence obtain a regional indicator of "identity". Similar to the analysis of economic assimilation, we derive the quartiles of this variable and interact them with the immigration rate. A similar procedure is carried out for the language ability indicators. In particular, we consider the variable "Own opinion of the respondent on the degree of spoken and written German". For the speaking and writing abilities of the immigrant, there are five possible answers: 1) Very good, 2) Good, 3) Not bad, 4) Fairly bad, and 5) Not at all. As before, we derive a dichotomous variable which is equal to 1 if the individual reports a value above the median and 0 if below. We then aggregate the values to obtain ROR indicators of subjective language performance. For each of the two variables (speaking and writing abilities), the quartiles of the distribution are obtained and each quartile is interacted with the immigration rate in the region.

\footnotetext{
${ }^{14}$ The construction of the variables is performed by considering only the group of immigrants. These questions are also asked to a subset of natives, mostly second generation immigrants, who are excluded from the calculations.
} 
In what follows, we assume that regions with a higher incidence of immigrants "feeling German" or with the ability to speak or write the German language are those which are more "assimilated". These assimilation measures go beyond the economic aspects of earnings and employment analysed in Table 6 and 7, also involving noneconomic factors which signal to what extent immigrants integrate with the host society. The results of regressions using these additional measures of assimilation are reported in Table 8. For natives the effect of immigration on well-being follows a very similar pattern to the case of economic assimilation, especially with reference to the "identity" variable and writing ability. In these two cases, it appears that the effect of immigration increases with the degree of socio-cultural assimilation in the region; however, in very high assimilated RORs the effect of immigration decreases to essentially zero as in the case of more objective measures of assimilation.

Table 8: Pseudo-objective and subjective measures of immigrant assimilation

\begin{tabular}{ccccccc}
\hline \hline & \multicolumn{2}{c}{ Feel German } & \multicolumn{2}{c}{ Write good German } & \multicolumn{2}{c}{ Speak good German } \\
& Natives & Immigrants & Natives & Immigrants & Natives & Immigrants \\
\hline IR x Q1 & $0.090^{* *}$ & $0.169^{*}$ & 0.055 & 0.163 & 0.039 & 0.161 \\
& $(0.035)$ & $(0.089)$ & $(0.042)$ & $(0.104)$ & $(0.047)$ & $(0.098)$ \\
IR x Q2 & $0.101^{* *}$ & 0.063 & $0.090^{* *}$ & $0.155^{*}$ & 0.034 & 0.076 \\
& $(0.045)$ & $(0.096)$ & $(0.038)$ & $(0.080)$ & $(0.034)$ & $(0.075)$ \\
IR x Q3 & $0.056^{* *}$ & -0.007 & $0.078^{* *}$ & -0.017 & 0.037 & 0.023 \\
& $(0.027)$ & $(0.076)$ & $(0.032)$ & $(0.079)$ & $(0.026)$ & $(0.067)$ \\
IR x Q4 & -0.047 & 0.134 & -0.005 & 0.030 & $0.143^{* * *}$ & 0.251 \\
& $(0.043)$ & $(0.089)$ & $(0.034)$ & $(0.103)$ & $(0.049)$ & $(0.220)$ \\
\hline \hline
\end{tabular}

Source: GSOEP 1997-2007 and INKAR 1997-2007 (GDP available only 1997-2006). Robust standard errors in parentheses. ${ }^{* * *}$ significant at $1 \%$; ${ }^{* *}$ significant at $5 \%$; ${ }^{*}$ significant at $10 \%$. All specifications are estimated using quasi fixed-effects and include the covariates of Table 2. Estimates in each panel refer to interactions between immigration rates (IR) and categorical variables for the regional assimilation index (obtained by estimating equations (3) and (4)) defined by the quartiles of its distribution (Q1, Q2, Q3, Q4).

\section{$7 \quad$ Endogeneity issues and robustness checks}

Studies which rely on regional variation to identify the impact of immigration on the labour market are usually subject to issues of endogeneity. The main source of endogeneity is that immigrants are typically not randomly distributed across labour markets. This may be due to the fact that natives respond to immigration by moving to regions with lower immigration, hence creating a spurious correlation between immigration and natives' outcomes (Filer, 1992). Alternatively, it might owe to im- 
migrants self-selecting as a function of labour market characteristics (Borjas, 1994, 2003). If such characteristics correspond to (or are correlated with) the outcome of interest and cannot be controlled for in the analysis, then omitted variable bias or simultaneity bias will arise. In absence of exogenous variation (e.g., see Card, 1990), analysis of the impact of immigration on outcomes such as earnings and employment are hence subject to the problem of causal interpretation. In the literature, the standard approach to addressing endogeneity has been to seek an instrumental variable which is correlated with the immigration rate but not with the outcome of interest. For example, Hatton and Tani (2005) use lagged immigration rates as an instrument for current immigration rates. Pischke and Velling (1997) use the past level of unemployment rate. Card (2001) constructs an instrument based on the flows by country of birth. Ortega and Peri (2009) use a similar "country of origin" approach, whereby immigration in the destination region is instrumented by the "pushing" migration factors exerted at the source region.

In general, the "quest" for an instrument is justified by the endogeneity issues between objective measures of natives' welfare and the immigration rate. Is the degree of endogeneity which could occur in the case of subjective outcomes the same as with objective outcomes such as wages? The panel structure of our data already allows us to control for ROR fixed-effects. This means that any unobservable timeinvariant factor correlated with immigration rate and SWB is already absorbed by the ROR dummies. Furthermore, the presence of time-varying regional characteristics controls for other unobservable factors which can influence the immigration rate. Thus, the presence of these variables already substantially mitigates the presence of endogeneity.

Yet in this section we explore the extent to which potential causality issues could affect our results in depth. Our findings suggest that endogeneity issues when using "subjective" outcomes to study the impact of immigration are much more negligible than when using "objective" outcomes. We explore endogeneity issues by first investigating whether natives "respond" to immigration by moving to regions where there are fewer immigrants, and then by examining whether immigrants sort into regions where natives are happier. We also carry out a second set of tests 
to ensure that our results are not affected by the selection of the sample or the definition of the immigration variable.

\subsection{Selection 1: Do unhappy natives vote with their feet?}

One of the important sources of selection bias is that natives living in a certain region decide to move to a different region as the number of immigrants changes in the region of origin. If the natives moving are actually those who experience a decrease in their utility as a consequence of immigration, then the remaining sample of natives will mechanically possess a high level of well-being. This may artificially generate the positive effect that we found above. If immigrants produce such a "displacement" effect, then the decision of natives to move away from the ROR will be positively correlated with immigration in the region of residence. This means that the probability of being displaced increases with the immigration rate. In order to directly test this hypothesis, we extract a sub-sample of natives who have changed ROR during the period of analysis (1997-2007) from the GSOEP, and use them to model the decision of internal migration as a function of the immigration rate. In practice we estimate the following linear regression model:

$$
\begin{aligned}
\text { move }_{i t} & =1\left[\mathbf{X}_{i t}^{\prime} \boldsymbol{\gamma}+\beta^{O} I R_{r t}^{O}+\beta^{D} I R_{r t}^{D}+\mathbf{Z}_{r t}^{\prime O} \boldsymbol{\lambda}^{O}+\mathbf{Z}_{r t}^{\prime D} \boldsymbol{\lambda}^{D}+\epsilon_{i t}>0\right] \\
\epsilon_{i t} & =\alpha_{i}+\delta_{r}+\theta_{t}+\varepsilon_{i t}
\end{aligned}
$$

where move is an indicator for whether a native individual moves from the ROR of origin $O$ to the ROR of destination $D$. In the regression, further to all socioeconomic covariates considered in the analysis so far $(\mathbf{X})$, we add the labour market characteristics of the ROR of origin $\left(\mathbf{Z}^{O}\right)$ and of the ROR of destination $\left(\mathbf{Z}^{D}\right)$. These include the unemployment rate (total and immigrant-specific) and GDP per capita. In equation (6), we control for the immigration rate in the origin $\mathrm{ROR}, I R^{O}$, and the immigration rate in the destination $\mathrm{ROR}, I R^{D}$. The error structure is identical to that in equation (2), and hence the model includes dummies for the ROR of residence $(\delta)$ and the time periods $(\theta)$. Furthermore, the probability of migrating is estimated through a $Q F E$ estimator, very much in line with the econometric 
strategy adopted so far. We report the results of these regressions in Table 9, where we estimate various alternatives of equation (6). We are particularly interested in the effect of the immigration rate in the origin. The estimate of the parameter $\beta^{O}$ informs about how the immigration rate in the ROR correlates with the probability of a native moving to a different region.

Table 9: Robustness checks

\begin{tabular}{|c|c|c|c|c|c|c|}
\hline \multirow[b]{2}{*}{ Immigration rate $(\mathrm{O})$} & \multicolumn{3}{|c|}{ Selection I: Native out-migration } & \multicolumn{3}{|c|}{ Selection II: Immigrants sorting } \\
\hline & $\begin{array}{r}0.0069 \\
00098)\end{array}$ & $\begin{array}{r}0.0021 \\
(0.0108)\end{array}$ & $\begin{array}{r}-0.0006 \\
(0.0130)\end{array}$ & & $\begin{array}{r}-0.0080 \\
(0.0345)\end{array}$ & 0.0003 \\
\hline Immigration rate $(\mathrm{D})$ & $0.0076^{* * *}$ & $0.0053^{* * *}$ & $0.0034^{* *}$ & & $\begin{array}{r}(0.0345) \\
-0.0045 \\
(0.0039)\end{array}$ & $\begin{array}{r}(0.0403) \\
-0.0058\end{array}$ \\
\hline Unemployment rate $(\mathrm{O})$ & & $(0.0037)$ & $\begin{array}{c}0.0143^{* * *} \\
(0.0046)\end{array}$ & & $(0.0150)$ & $\begin{array}{c}0.0379^{* *} \\
(0.0171)\end{array}$ \\
\hline Unemployment rate (D) & & $\begin{array}{l}-0.0058^{* * *} \\
(0.0010)\end{array}$ & $\begin{array}{l}-0.0059^{* * *} \\
(0.0012)\end{array}$ & & $\begin{array}{r}0.0020 \\
(0.0046)\end{array}$ & $\begin{array}{r}0.0019 \\
(0.0057)\end{array}$ \\
\hline Per capita log GDP $(\mathrm{O})$ & & & $\begin{array}{r}0.1699 \\
(0.1339)\end{array}$ & & & $\begin{array}{r}0.5620 \\
(0.5023)\end{array}$ \\
\hline Per capita log GDP (D) & & & $\begin{array}{r}0.0496 \\
(0.0318)\end{array}$ & & & $\begin{array}{c}-0.0032 \\
(0.1263)\end{array}$ \\
\hline SWB $(\mathrm{O})$ & & & & $\begin{array}{r}0.0208 \\
(0.0464)\end{array}$ & $\begin{array}{l}-0.1101^{* *} \\
(0.0553)\end{array}$ & $\begin{array}{l}-0.0727 \\
(0.0682)\end{array}$ \\
\hline SWB (D) & & & & $\begin{array}{l}-0.0055 \\
(0.0376)\end{array}$ & $\begin{array}{r}0.0552 \\
(0.0442)\end{array}$ & $\begin{array}{r}0.0421 \\
(0.0531)\end{array}$ \\
\hline$R^{2}$ & 0.079 & 0.083 & 0.039 & 0.134 & 0.144 & 0.121 \\
\hline $\mathrm{N}$ & 31,398 & 29,148 & 26,448 & 3,942 & 3,588 & 3,300 \\
\hline
\end{tabular}

Source: GSOEP 1997-2007 and INKAR 1997-2007 (GDP available only 1997-2006). Robust standard errors in parentheses. ${ }^{* * *}$ significant at $1 \%$; ${ }^{* *}$ significant at $5 \% ;{ }^{*}$ significant at $10 \%$. All specifications are estimated using quasi fixed-effects and include the covariates of Table 2 .

The first column in Table 9 only includes immigration rates in the ROR of origin and destination. The estimates reveal that while immigration in the area of origin is positively correlated with the probability of moving, the size of the estimate is statistically insignificant. On the other hand, immigration in the destination areas appears to be a "pull factor" for natives. However, this effect could be obfuscated by other regional factors in the regions of origin and destination. For this reason, in the second column we add local unemployment rates and per capita GDP. While the effect of income appears to be irrelevant, the unemployment rate is a strong predictor for the probability of migration. In particular - and as predicted by economic theory - higher local unemployment in the region of origin induces natives to out-migrate, while higher unemployment in the destination decreases the probability of changing ROR. Remarkably, after controlling for these additional origin and destination local market characteristics, the immigration rate in the origin has essentially no impact 
on the probability of out-migration. Given these findings, it is possible to conclude that natives are not crowded out by the immigration rate, and hence our benchmark results are unlikely to be affected by this sort of self-selection.

\subsection{Selection 2: Do migrants move to happier regions?}

Another potential source of endogeneity is that the immigrants sort themselves in regions where well-being is higher. If this is the case, reverse causality could potentially arise and the observed immigration rate would itself be a function of SWB. Before investigating this issue, it is informative to provide a brief account of the historical patterns of immigration in Germany. Most of the earlier cohorts of immigrants moved to Germany through "guest workers programmes", through bilateral recruitment contracts stipulated between Germany and partner countries (for example, Turkey, Italy and Greece). After 1973, the programme was formally closed: albeit immigration to guest workers regions continued through other channels, such as family reunification. However, recent patterns of immigration have changed dramatically, especially after the fall of the Berlin wall (a relevant discussion about immigration in Germany is given in Pischke and Velling, 1997 and D'Amuri et al., 2010). As a consequence, the "immigration rate" observed in a given region is the likely outcome of many complex factors such as economic characteristics and the presence of ethnic networks in the region of destination. The characteristics that determine the sorting of immigrants into a particular region - many of which are unobservable to the researcher - are often correlated with the outcome of interest (in our case SWB). By introducing fixed-ROR effects, the estimation strategy used in this paper allows to control for all regional time-invariant characteristics. To further control for the sorting of immigrants driven by time-variant "shocks" in the region, our models includes regional characteristics, such as unemployment rate and GDP per capita. Yet if immigrants decide to migrate internally after arrival in Germany, and if the SWB in the region of destination is a major determinant of this decision, the estimated impact of immigration on well-being will be affected by reverse causality.

To investigate this issue, we mimic the procedure above and select a sub-sample 
of immigrants who have changed ROR during 1997-2007 from the data. We estimate the same model as in equation (6), and add as control variables the average level of well-being in the ROR of origin and destination. If the average SWB in a region is a significant determinant of the internal sorting of immigrants, then one would expect to find strong positive correlation between the decision to migrate and the average level of well-being in the ROR of destination. However, the results in the fourth to sixth column of Table 9 reveal a different picture. The well-being in the destination is not found to be a strong magnet for internal migration in any of the three specifications. Instead, the major factor "pushing" out immigrants from a ROR is the unemployment rate - as found in previous studies. Based on this result we conclude that the effect of immigrants' sorting due to higher SWB in regions is weak. However, below we further investigate this issue with various alternative robustness checks.

\subsection{Sensitivity tests}

The previous section highlights that our results are not likely to be substantially affected by natives' crowding-out or by immigrants' sorting. In this section, we conduct further tests to assess the sensitivity of our analysis to the selection of our sample and the definition of the immigration variable. The results from these additional tests are reported in Table 10. First, and to further corroborate the findings of Table 9, we explore whether there are substantial differences between the sample of movers (individuals who have changed ROR) and stayers. Table 9 has already shown the natives are not crowded out because of immigration. Thus, we expect that the effect of the immigration rate for those who move out of the ROR and those who never changed ROR would generate similar results. This is essentially what we find in the second column of Table 10 where estimates are slightly larger, albeit borderline significant at conventional levels. The same conclusion is reached in the case of immigrants, although, very much in line with the findings so far, the estimates are not statistically significant.

We then explore whether our results are confirmed if we consider West and East Germany separately. Since immigration patterns (as well as macroeconomic 
Table 10: Further tests

\begin{tabular}{lcrrrrrr}
\hline \hline & Movers & Stayers & West & East & $\begin{array}{c}\text { Excl. top } \\
\text { IR ROR }\end{array}$ & $\begin{array}{c}\text { Excl. top } \\
\text { SWB ROR }\end{array}$ & $\begin{array}{c}\text { Net inflow } \\
\text { rate }\end{array}$ \\
\hline & \multicolumn{7}{c}{ Selection I: Native out-migration } \\
\hline Immigration rate & $0.096^{*}$ & $0.038^{* *}$ & $0.034^{*}$ & $0.183^{* * *}$ & $0.101^{* * *}$ & $0.070^{* * *}$ & $0.015^{* *}$ \\
& $(0.055)$ & $(0.019)$ & $(0.021)$ & $(0.058)$ & $(0.027)$ & $(0.019)$ & $(0.007)$ \\
$R^{2}$ & 0.263 & 0.281 & 0.253 & 0.268 & 0.281 & 0.275 & 0.052 \\
$\mathrm{~N}$ & 9,556 & 108,107 & 84,941 & 32,722 & 89,862 & 109,323 & 92,535 \\
\hline & \multicolumn{7}{c}{ Selection II: Immigrants sorting } \\
\hline Immigration rate & 0.110 & 0.059 & 0.068 & 0.029 & $0.175^{* *}$ & 0.070 & 0.036 \\
$R^{2}$ & $(0.197)$ & $(0.049)$ & $(0.049)$ & $(0.518)$ & $(0.072)$ & $(0.052)$ & $(0.032)$ \\
$\mathrm{N}$ & 0.369 & 0.273 & 0.267 & 0.373 & 0.282 & 0.266 & 0.062 \\
\hline \hline
\end{tabular}

Source: GSOEP 1997-2007 and INKAR 1997-2007 (GDP available only 1997-2006). Robust standard errors in parentheses. ${ }^{* * *}$ significant at $1 \% ;{ }^{* *}$ significant at $5 \% ;{ }^{*}$ significant at $10 \%$. Movers are defined as individuals who live in a different ROR than the previous year. The excluded top migrant RORs correspond to the regions that make up the upper quartile of the immigration rate distribution (10 RORs). The excluded top SWB RORs correspond to the regions that make up the upper quartile of the SWB distribution (28 RORs). The immigration net flow rate corresponds to the difference between the number of foreign born individuals moving into a ROR and those moving out of the ROR, divided by current population in the ROR. All specifications are estimated using quasi fixed-effects and include the covariates of Table 2. ROR and year dummies are included in all models except the one in the last column.

fundamentals, and levels of well-being) differ substantially between the two areas, one wonders whether our benchmark results will be different as well. The results in the third and fourth column of Table 10 appear to confirm our predictions. In particular, in the West the effect of immigration on SWB is somewhat smaller than the benchmark result, while in the East the estimate is far larger. Conversely, for the sample of immigrants, the point estimate for the West area is very close to the benchmark results, while the estimate for the East is somewhat negative, but also considerably imprecise due to the very small sample size.

In the fifth and sixth column we investigate how the results change when we exclude top immigration RORs or those with the highest levels of well-being. The rationale for these restrictions is to test whether our results are driven entirely by regions which absorb large inflows of immigrants (RORs which contain the largest cities) or by particularly "happy" regions which might affect the sorting of immigrants (or of natives). When we exclude the top 10 RORs, the effect of immigration on the well-being of natives becomes more than two times larger than the benchmark result. This suggests that the estimated effect is not driven by major migrant destinations in Germany. When we exclude the upper quartile of regions in terms of subjective well-being (28 RORs), the results are slightly larger than those in Table 2. One key remark for the group of immigrants is that by excluding top immigra- 
tion destinations, the impact of immigration on well-being becomes substantially large and highly statistically significant. One possible explanation is that in top immigration RORs, labour competition among immigrants is rather strong and this generates some disutility, at least with respect to the observed level of well-being in RORs with lower immigrant populations.

Finally, in the last column we explore the sensitivity of our results to the choice of the immigration variable used. To this aim, we use information on immigrant net inflow rate (rather than immigrant stocks in the region), constructed as the difference between the inflows and outflows of immigrants in a ROR. This allows us to assess how sensitive our results are to the use of an alternative immigration variable. In practice, we estimate a model similar to that in equation (1), except that all variables are expressed in first differences. This is because the net inflow rate of immigrants is itself a measure of change over time. The only difference from the specifications used so far is that we omit the ROR fixed-effects, because unobservable, local-specific characteristics are mechanically differenced out. A similar approach using measures of flows without "destination dummies" is adopted in Ortega and Peri (2009). The results reveal a pattern that is remarkably similar to the one found when we use immigration stocks, albeit the estimates for both natives and immigrants are somewhat smaller when compared to the benchmark results.

\subsection{Domain specific well-being: is the impact similar?}

As further robustness checks, we explore in more depth our measure of well-being. So far, we have not been concerned with understanding what dimensions of well-being are particularly affected by immigration. Although a comprehensive investigation of this issue is beyond the scope of this paper, we are interested in exploring whether our results differ substantially across specific "domains" of well-being. These could be interpreted as components of the measure of well-being used so far. In practice, we look at five "satisfaction" dimensions: job, health, income, dwelling and leisure. While these do not constitute a complete taxonomy, they allow for the investigation of aspects of life which are more sensitive to being affected by immigration.

The results in Table 11 reveal that the impact of immigration on natives' job sat- 
Table 11: Immigration and domain-specific SWB

\begin{tabular}{lrrrrr}
\hline \hline & \multicolumn{1}{c}{ Job } & Health & Income & Dwelling & Leisure \\
\hline Immigration rate & -0.005 & 0.021 & 0.027 & $0.138^{* * *}$ & $0.066^{* * *}$ \\
& $(0.023)$ & $(0.014)$ & $(0.019)$ & $(0.020)$ & $(0.022)$ \\
$R^{2}$ & 0.166 & 0.587 & 0.321 & 0.109 & 0.123 \\
$\mathrm{~N}$ & 100,401 & 139,007 & 137,215 & 138,503 & 138,776 \\
\hline \multicolumn{5}{c}{ Immigrants } \\
\hline Immigration rate & 0.075 & $0.073^{* *}$ & 0.016 & -0.008 & $0.129^{* *}$ \\
$R^{2}$ & $(0.064)$ & $(0.036)$ & $(0.051)$ & $(0.053)$ & $(0.054)$ \\
$\mathrm{N}$ & 0.228 & 0.592 & 0.302 & 0.152 & 0.181 \\
\hline \hline
\end{tabular}

Source: GSOEP 1997-2007 and INKAR 1997-2007 (GDP available only 1997-2006). Robust standard errors in parentheses. ${ }^{* * *}$ significant at $1 \%$; ${ }^{* *}$ significant at $5 \%$; * significant at $10 \%$. Movers are defined as individuals who live in a different ROR than the previous year. Job correspond to the question "Satisfaction With Work"; Health correspond to the question "Satisfaction With Health"; Income correspond to the question "Satisfaction With Household Income"; Dwelling correspond to the question "Satisfaction With Dwelling"; Leisure correspond to the question "Satisfaction With Amount of Leisure Time". All specifications are estimated using quasi fixed-effects and include the covariates of Table 2.

isfaction is essentially zero, both economically and statistically. Neither the health nor the income satisfaction of natives appears to be affected by immigration. On the other hand our results indicate that satisfaction with dwelling and leisure appear to be the most affected domains. One possibility, albeit speculative, is that a higher immigration rate also lowers house rental prices for German-born individuals. This is compatible with the fact that natives do not move out as immigration increases, as seen in Table 9. As for leisure satisfaction, one potential interpretation is that immigrants bring amenities - such as "ethnic" or "multicultural" goods - which can increase the well-being of natives in terms of their living habits. For immigrants, the impact of immigration on well-being appears to be economically and statistically relevant in two domains, namely health and leisure satisfaction. These results are compatible with the findings of section 5 , where it was shown that the assimilation of immigrants is found to be "neutral" in terms of labour market effects, while sociocultural integration has a positive impact - at least for certain levels of assimilation - on individuals' well-being. 


\section{Conclusion}

This paper provides an innovative approach to directly testing the impact of immigration on the "utility" of natives. To the best of our knowledge, this is the first paper to explore such nexus. We exploit techniques developed in the well-being literature to answer a question at the heart of the economics of immigration: "What is the impact of immigration on the native population?" Hence we go beyond the traditional approach of only analysing labour market outcomes, and we consider the impact of immigration on a more comprehensive measure of utility, namely overall subjective well-being.

Merging panel data with detailed information on German local labour markets for the period 1997-2007, we explore how immigration in the region affects the well-being of natives and immigrants. Our major finding is that an increase of immigration in the region positively affects the well-being of natives. In other words, German-born individuals obtain welfare gains as immigration in their region of residence increases. For immigrants, we find similar results, albeit they are less robust throughout the many tests conducted. In the analysis, we control for a series of confounding factors at both the individual and regional level. In particular, we find that controlling for local labour market conditions does not influence our findings, a result which can be seen as a corollary of recent evidence that immigration does not have a detrimental effect on the German labour market (D'Amuri et al., 2010). We also investigate the effect of sorting by natives and immigrants. Our analysis suggests that the impact of sorting is not strong, given our subjective outcome.

One of the novel and important findings in this paper indicates that the impact of immigration is also a function of the degree of economic and cultural assimilation of immigrants in the region. According to our results, immigration increases wellbeing up to a certain level of an "assimilation threshold", beyond which its effect becomes essentially zero. This is perhaps the most important finding of the paper, and the investigation of the channels behind this result, as well its potential policy implications, will form the scope of future research. 


\section{References}

Barth, E., B. Bratsberg, and O. Raaum (2004). Identifying earnings assimilation of immigrants under changing macroeconomic conditions. The Scandinavian Journal of Economics 106(1), 1-22.

Boeri, T. (2010). Immigration to the land of redistribution. Economica $77(308)$, $651-687$.

Borjas, G. (1985). Assimilation, changes in cohort quality, and the earnings of immigrants. Journal of labor Economics 3(4), 463-89.

Borjas, G. (1994). The economics of immigration. Journal of Economic Literature 32(4), 1667-1717.

Borjas, G. (1999). The economic analysis of immigration. In Ashenfelter, O. and D.E. Card (Ed.), Handbook of labor economics, Volume 3, pp. 1697-1760. Elsevier.

Borjas, G. (2003). The labor demand curve is downward sloping: Reexamining the impact of immigration on the labor market. Quarterly Journal of Economics 118(4), 1335-1374.

Boyce, C. (2010). Understanding fixed effects in human well-being. Journal of Economic Psychology 31(1), 1-16.

Brücker, H., G. Epstein, B. McCormick, G. Saint-Paul, A. Venturini, and K. Zimmermann (2002). Managing migration in the European welfare state. In Boeri, T. and Hanson, G. and McCormick, B. (Ed.), Immigration Policy and the Welfare System, pp. 1-167. Oxford University Press.

Butcher, K. and D. Card (1991). Immigration and wages: Evidence from the 1980's. The American Economic Review 81(2), 292-296.

Card, D. (1990). The impact of the mariel boatlift on the Miami labor market. Industrial and Labor Relations Review 43(2), 245-257.

Card, D. (2001). Immigrant inflows, native outflows, and the local labor market impacts of higher immigration. Journal of Labor Economics 19(1), 22-64. 
Card, D. (2005). Is the new immigration really so bad? The Economic Journal 115(507), F300-F323.

Chamberlain, G. (1984). Panel Data. In Griliches, Z. and M.D. Intriligator (Ed.), Handbook of Econometrics, Volume 2, pp. 1247-1318. North Holland.

Chiswick, B. (1978). The effect of Americanization on the earnings of foreign-born men. The Journal of Political Economy 86(5), 897-921.

Clark, A. (2003). Unemployment as a social norm: Psychological evidence from panel data. Journal of Labor Economics 21(2), 289-322.

Clark, A., P. Frijters, and M. Shields (2008). Relative income, happiness, and utility: An explanation for the Easterlin paradox and other puzzles. Journal of Economic Literature 46(1), 95-144.

Clark, A. and A. Oswald (1994). Unhappiness and unemployment. The Economic Journal 104(424), 648-659.

Clark, A. and A. Oswald (1996). Satisfaction and comparison income. Journal of public economics $61(3), 359-381$.

D'Amuri, F., G. Ottaviano, and G. Peri (2010). The labor market impact of immigration in Western Germany in the 1990s. European Economic Review 54(4), $550-570$.

Deaton, A. (2008). Income, health, and well-being around the world: Evidence from the Gallup World Poll. Journal of Economic Perspectives 22(2), 53-72.

Dolan, P., T. Peasgood, and M. White (2008). Do we really know what makes us happy? A review of the economic literature on the factors associated with subjective well-being. Journal of Economic Psychology 29(1), 94-122.

Dustmann, C., F. Fabbri, and I. Preston (2005). The impact of immigration on the British labour market. Economic Journal 115(507), F324-F341.

Dustmann, C., T. Frattini, and C. Halls (2010). Assessing the fiscal costs and benefits of A8 migration to the UK. Fiscal Studies 31(1), 1-41. 
Easterlin, R. (1995). Will raising the incomes of all increase the happiness of all? Journal of Economic Behavior $\& 5$ Organization 27(1), 35-47.

Ferrer-i Carbonell, A. (2005). Income and well-being: An empirical analysis of the comparison income effect. Journal of Public Economics 89(5-6), 997-1019.

Ferrer-i Carbonell, A. and P. Frijters (2004). How important is methodology for the estimates of the determinants of happiness? The Economic Journal 114(497), 641-659.

Filer, R. (1992). The effect of immigrant arrivals on migratory patterns of native workers. In G. Borjas and R. Freeman (Eds.), Immigration and the Work Force: Economic Consequences for the United States and Source Areas, pp. 245-269. University Chicago Press.

Fleurbaey, M. (2009). Beyond GDP: The quest for a measure of social welfare. Journal of Economic Literature 47(4), 1029-1075.

Frey, B. and A. Stutzer (2002). What can economists learn from happiness research? Journal of Economic Literature 40(2), 402-435.

Friedberg, R. and J. Hunt (1995). The impact of immigrants on host country wages, employment and growth. The Journal of Economic Perspectives 9(2), 23-44.

Hatton, T. and M. Tani (2005). Immigration and inter-regional mobility in the UK, 1982-2000. Economic Journal 115(507), F342-F358.

Kahneman, D. and R. Sugden (2005). Experienced utility as a standard of policy evaluation. Environmental and resource economics 32(1), 161-181.

Knies, G. and C. Spiess (2007). Regional data in the German Socio-Economic Panel Study (SOEP). DIW Data Documentation 17.

Luttmer, E. (2005). Neighbors as negatives: Relative earnings and well-being. The Quarterly Journal of Economics 120(3), 963-1002. 
Manacorda, M., A. Manning, and J. Wadsworth (2012). The impact of immigration on the structure of wages: Theory and evidence from Britain. Journal of the European Economic Association 10(1), 120-151.

Ortega, F. and G. Peri (2009). The causes and effects of international migrations: Evidence from OECD countries 1980-2005. NBER Working Papers 14833.

Ottaviano, G. and G. Peri (2012). Rethinking the effects of immigration on wages. Journal of the European Economic Association 10(1), 152-197.

Pischke, J. and J. Velling (1997). Employment effects of immigration to Germany: An analysis based on local labor markets. Review of Economics and Statistics $79(4), 594-604$.

Senik, C. (2004). When information dominates comparison: Learning from Russian subjective panel data. Journal of Public Economics 88(9-10), 2099-2123.

Simpson, N. (2012). Happiness and Migration. In Constant, A.F. and K.F. Zimmermann (Ed.), International Handbook on the Economics of Migration. Edward Elgar Publishing, forthcoming.

Stiglitz, J., A. Sen, and J. Fitoussi (2009). Report by the commission on the measurement of economic performance and social progress. Accessed on 22 February 2012 at: http://www.stiglitz-sen-fitoussi.fr/en/index.htm.

Van Praag, B., P. Frijters, and A. Ferrer-i Carbonell (2003). The anatomy of subjective well-being. Journal of Economic Behavior \& Organization 51(1), 29-49.

Winkelmann, L. and R. Winkelmann (1998). Why are the unemployed so unhappy? Evidence from panel data. Economica 65(257), 1-15. 


\section{Appendix}

Table A1: Immigration and SWB: Benchmark results - natives

\begin{tabular}{|c|c|c|c|c|c|}
\hline & OLS & OP & $\overline{\mathrm{RE}}$ & $\overline{\mathrm{FE}}$ & QFE \\
\hline Immigration rate & $0.043^{* * *}$ & $0.031^{* * *}$ & $0.042^{* * *}$ & $0.040^{* *}$ & $0.046^{* * *}$ \\
\hline Age & $\begin{array}{l}(0.014) \\
-0.086^{* * *}\end{array}$ & $\begin{array}{l}(0.010) \\
-0.058^{* * *}\end{array}$ & $\begin{array}{l}(0.015) \\
-0.076^{* * *}\end{array}$ & $\begin{array}{l}(0.016) \\
-0.033^{* * *}\end{array}$ & $\begin{array}{l}(0.015) \\
-0.190^{* * *}\end{array}$ \\
\hline & $(0.003)$ & $(0.002)$ & $(0.004)$ & $(0.007)$ & $(0.006)$ \\
\hline Age squared & $\begin{array}{l}0.001^{* * * *} \\
(0.000)\end{array}$ & $\begin{array}{l}0.001^{* * *} \\
(0.000)\end{array}$ & $\begin{array}{l}0.001 * * * \\
(0.000)\end{array}$ & $\begin{array}{l}0.000^{* * * *} \\
(0.000)\end{array}$ & $\begin{array}{l}0.001 * * * \\
(0.000)\end{array}$ \\
\hline Female & $\begin{array}{l}0.119 * * * \\
(0.009)\end{array}$ & $\begin{array}{l}0.084^{* * *} \\
(0.006)\end{array}$ & $\begin{array}{l}0.139^{* * *} \\
(0.015)\end{array}$ & & $\begin{array}{l}0.119^{* * *} \\
(0.015)\end{array}$ \\
\hline East Germany & $\begin{array}{l}-0.332^{* * *} \\
(0.026)\end{array}$ & $\begin{array}{l}-0.234^{* * *} \\
(0.017)\end{array}$ & $\begin{array}{l}-0.406^{* * *} \\
(0.032)\end{array}$ & $\begin{array}{l}-0.201 \text { *** } \\
(0.064)\end{array}$ & $\begin{array}{l}-0.335^{* * *} \\
(0.032)\end{array}$ \\
\hline Years of education & $\begin{array}{l}0.010^{* * *} \\
(0.002)\end{array}$ & $\begin{array}{l}0.007^{* * *} \\
(0.001)\end{array}$ & $\begin{array}{l}0.026^{* * *} \\
(0.003)\end{array}$ & $\begin{array}{r}0.003 \\
(0.007)\end{array}$ & $\begin{array}{c}0.013^{*} \\
(0.007)\end{array}$ \\
\hline Log household size & $\begin{array}{l}-0.376^{* * *} \\
(0.016)\end{array}$ & $\begin{array}{l}-0.256^{* * *} \\
(0.011)\end{array}$ & $\begin{array}{l}-0.244^{* * *} \\
(0.021)\end{array}$ & $\begin{array}{l}-0.171^{* * *} \\
(0.026)\end{array}$ & $\begin{array}{l}-0.176^{* * *} \\
(0.024)\end{array}$ \\
\hline One child & $\begin{array}{l}0.097^{* * *} \\
(0.013)\end{array}$ & $\begin{array}{l}0.062^{* * *} \\
(0.009)\end{array}$ & $\begin{array}{l}0.095^{* * *} \\
(0.015)\end{array}$ & $\begin{array}{l}0.113^{* * *} \\
(0.018)\end{array}$ & $\begin{array}{l}0.101^{* * *} \\
(0.015)\end{array}$ \\
\hline Two children & $\begin{array}{l}0.199^{* * *} \\
(0.016)\end{array}$ & $\begin{array}{l}0.127^{* * *} \\
(0.011)\end{array}$ & $\begin{array}{l}0.163^{* * *} \\
(0.021)\end{array}$ & $\begin{array}{l}0.166^{* * *} \\
(0.026)\end{array}$ & $\begin{array}{l}0.178^{* * *} \\
(0.021)\end{array}$ \\
\hline Three or more children & $\begin{array}{l}0.234^{* * *} \\
(0.025)\end{array}$ & $\begin{array}{l}0.169^{* * *} \\
(0.017)\end{array}$ & $\begin{array}{l}0.173^{* * *} \\
(0.034)\end{array}$ & $\begin{array}{l}0.190^{* * * *} \\
(0.044)\end{array}$ & $\begin{array}{l}0.194^{* * *} \\
(0.034)\end{array}$ \\
\hline Separated & $\begin{array}{l}-0.580^{* * *} \\
(0.034)\end{array}$ & $\begin{array}{l}-0.364^{* * * *} \\
(0.022)\end{array}$ & $\begin{array}{l}-0.431^{* * *} \\
(0.040)\end{array}$ & $\begin{array}{l}-0.296^{* * *} \\
(0.047)\end{array}$ & $\begin{array}{l}-0.429^{* * *} \\
(0.040)\end{array}$ \\
\hline Single & $\begin{array}{l}-0.281^{* * *} \\
(0.015)\end{array}$ & $\begin{array}{l}-0.194^{* * *} \\
(0.010)\end{array}$ & $\begin{array}{l}-0.221 \text { *** } \\
(0.022)\end{array}$ & $\begin{array}{l}-0.159^{* * *} \\
(0.032)\end{array}$ & $\begin{array}{l}-0.212^{* * *} \\
(0.022)\end{array}$ \\
\hline Divorced & $\begin{array}{l}-0.311^{* * *} \\
(0.017)\end{array}$ & $\begin{array}{l}-0.203^{* * *} \\
(0.012)\end{array}$ & $\begin{array}{l}-0.208^{* * *} \\
(0.026)\end{array}$ & $\begin{array}{r}0.016 \\
(0.041)\end{array}$ & $\begin{array}{l}-0.188^{* * *} \\
(0.026)\end{array}$ \\
\hline Widowed & $\begin{array}{l}-0.290^{* * *} \\
(0.032)\end{array}$ & $\begin{array}{l}-0.188^{* * *} \\
(0.021)\end{array}$ & $\begin{array}{l}-0.334^{* * *} \\
(0.053)\end{array}$ & $\begin{array}{l}-0.531^{* * *} \\
(0.098)\end{array}$ & $\begin{array}{l}-0.317^{* * *} \\
(0.053)\end{array}$ \\
\hline Spouse in native country & $\begin{array}{l}-0.063 \\
(0.145)\end{array}$ & $\begin{array}{l}-0.148 \\
(0.100)\end{array}$ & $\begin{array}{l}-0.079 \\
(0.057)\end{array}$ & $\begin{array}{l}0.285^{* * *} \\
(0.050)\end{array}$ & $\begin{array}{r}0.055 \\
(0.066)\end{array}$ \\
\hline Very good & $\begin{array}{l}1.082^{\text {*** }} \\
(0.135)\end{array}$ & $\begin{array}{l}0.836^{* * *} \\
(0.090)\end{array}$ & $\begin{array}{l}0.777^{* * *} \\
(0.124)\end{array}$ & $\begin{array}{l}0.577^{* * *} \\
(0.128)\end{array}$ & $\begin{array}{l}0.763^{* * *} \\
(0.124)\end{array}$ \\
\hline Good & $\begin{array}{l}0.504^{* * *} \\
(0.134)\end{array}$ & $\begin{array}{l}0.328^{* * *} \\
(0.090)\end{array}$ & $\begin{array}{l}0.360^{* * *} \\
(0.124)\end{array}$ & $\begin{array}{c}0.267^{* *} \\
(0.127)\end{array}$ & $\begin{array}{l}0.356^{* * *} \\
(0.124)\end{array}$ \\
\hline Satisfactory & $\begin{array}{l}-0.259^{*} \\
(0.135)\end{array}$ & $\begin{array}{l}-0.217^{* *} \\
(0.090)\end{array}$ & $\begin{array}{l}-0.174 \\
(0.124)\end{array}$ & $\begin{array}{l}-0.142 \\
(0.127)\end{array}$ & $\begin{array}{l}-0.171 \\
(0.124)\end{array}$ \\
\hline Poor & $\begin{array}{l}-1.048^{* * *} \\
(0.135)\end{array}$ & $\begin{array}{l}-0.692^{* * *} \\
(0.090)\end{array}$ & $\begin{array}{l}-0.808^{* * *} \\
(0.125)\end{array}$ & $\begin{array}{l}-0.668^{* * *} \\
(0.128)\end{array}$ & $\begin{array}{l}-0.799^{* * *} \\
(0.124)\end{array}$ \\
\hline $\mathrm{Bad}$ & $\begin{array}{l}-2.339^{* * *} \\
(0.140)\end{array}$ & $\begin{array}{l}-1.356^{* * *} \\
(0.092)\end{array}$ & $\begin{array}{l}-1.880^{* * *} \\
(0.132)\end{array}$ & $\begin{array}{l}-1.581^{* * *} \\
(0.137)\end{array}$ & $\begin{array}{l}-1.866^{* * *} \\
(0.132)\end{array}$ \\
\hline Not in labour force & $\begin{array}{r}0.003 \\
(0.027)\end{array}$ & $\begin{array}{l}-0.001 \\
(0.019)\end{array}$ & $\begin{array}{l}-0.007 \\
(0.026)\end{array}$ & $\begin{array}{l}-0.016 \\
(0.027)\end{array}$ & $\begin{array}{l}-0.015 \\
(0.026)\end{array}$ \\
\hline Retired & $\begin{array}{r}-0.040 \\
(0.069)\end{array}$ & $\begin{array}{l}-0.037 \\
(0.049)\end{array}$ & $\begin{array}{l}-0.030 \\
(0.062)\end{array}$ & $\begin{array}{l}-0.053 \\
(0.070)\end{array}$ & $\begin{array}{r}-0.030 \\
(0.062)\end{array}$ \\
\hline In school/training & $\begin{array}{l}0.107^{* * * *} \\
(0.037)\end{array}$ & $\begin{array}{l}0.052^{* *} \\
(0.026)\end{array}$ & $\begin{array}{l}0.158^{* * *} \\
(0.037)\end{array}$ & $\begin{array}{l}0.100^{* *} \\
(0.041)\end{array}$ & $\begin{array}{l}0.126^{* * *} \\
(0.037)\end{array}$ \\
\hline Unemployed & $\begin{array}{l}-0.716^{* * *} \\
(0.032)\end{array}$ & $\begin{array}{l}-0.433^{* * *} \\
(0.021)\end{array}$ & $\begin{array}{l}-0.538^{* * *} \\
(0.032)\end{array}$ & $\begin{array}{l}-0.468^{* * *} \\
(0.034)\end{array}$ & $\begin{array}{l}-0.541^{* * *} \\
(0.032)\end{array}$ \\
\hline Self-employed & $\begin{array}{l}-0.127^{* * *} \\
(0.016)\end{array}$ & $\begin{array}{l}-0.070^{* * * *} \\
(0.011)\end{array}$ & $\begin{array}{l}-0.049^{* *} \\
(0.024)\end{array}$ & $\begin{array}{r}0.028 \\
(0.034)\end{array}$ & $\begin{array}{l}-0.058^{* *} \\
(0.024)\end{array}$ \\
\hline Log wage & $\begin{array}{l}0.006^{* * *} \\
(0.002)\end{array}$ & $\begin{array}{l}0.004^{* * *} \\
(0.001)\end{array}$ & $\begin{array}{l}0.007^{* * *} \\
(0.002)\end{array}$ & $\begin{array}{r}0.003 \\
(0.002)\end{array}$ & $\begin{array}{l}0.006^{* * *} \\
(0.002)\end{array}$ \\
\hline Log working hours & $\begin{array}{r}0.001 \\
(0.007)\end{array}$ & $\begin{array}{l}-0.006 \\
(0.005)\end{array}$ & $\begin{array}{l}0.021^{* * *} \\
(0.007)\end{array}$ & $\begin{array}{l}0.028^{* * *} \\
(0.007)\end{array}$ & $\begin{array}{l}0.026^{* * *} \\
(0.007)\end{array}$ \\
\hline Log household income & $\begin{array}{l}0.601^{* * *} \\
(0.012)\end{array}$ & $\begin{array}{l}0.412^{* * *} \\
(0.009)\end{array}$ & $\begin{array}{l}0.462^{* * *} \\
(0.016)\end{array}$ & $\begin{array}{l}0.324^{* * *} \\
(0.019)\end{array}$ & $\begin{array}{l}0.311^{* * *} \\
(0.018)\end{array}$ \\
\hline$R^{2}$ & 0.277 & 0.083 & 0.271 & 0.232 & 0.277 \\
\hline
\end{tabular}

$\overline{\overline{\text { Robust standard errors in parentheses. }{ }^{* * *} \text { significant at } 1 \%{ }^{* *} \text { significant at } 5 \% \text {; }{ }^{*} \text { significant }}}$ at 10\%. OLS=Ordinary least square; $\mathrm{OP}=$ Ordered probit; $\mathrm{RE}=$ Random-effects; $\mathrm{FE}=$ Fixed-effects; $\mathrm{QFE}=\mathrm{Quasi}$ fixed-effects. All specifications include ROR indicators and year dummies. QFE includes also individual averages over time of age, log household size, years of education, log household income and log working hours. The $R^{2}$ for the OP specification refers to pseudo- $R^{2}$. 
Table A2: Immigration and SWB: Benchmark results - immigrants

\begin{tabular}{|c|c|c|c|c|c|}
\hline & OLS & OP & $\overline{\mathrm{RE}}$ & FE & QFE \\
\hline \multirow{2}{*}{ Immigration rate } & $0.078^{* *}$ & $0.063^{* *}$ & 0.064 & 0.053 & $0.066^{*}$ \\
\hline & $(0.038)$ & $(0.025)$ & $(0.040)$ & $(0.043)$ & $(0.040)$ \\
\hline \multirow[t]{2}{*}{ Age } & $-0.075^{* * *}$ & $-0.050^{* * *}$ & $-0.084^{* * *}$ & $-0.058^{* * *}$ & $-0.176^{* * *}$ \\
\hline & $\begin{array}{l}(0.007) \\
0.001 * * *\end{array}$ & $\begin{array}{l}(0.005) \\
0.001 * * *\end{array}$ & $\begin{array}{l}(0.011) \\
0.001 * * *\end{array}$ & $\begin{array}{l}(0.018) \\
0.001 * * *\end{array}$ & $\begin{array}{l}(0.016) \\
0.001 * * *\end{array}$ \\
\hline Age squared & $(0.000)$ & $(0.000)$ & $(0.000)$ & $(0.000)$ & $(0.000)$ \\
\hline \multirow[t]{2}{*}{ Female } & $0.192^{* * *}$ & $0.125^{* * *}$ & $0.207^{* * *}$ & & $0.174^{* * *}$ \\
\hline & $(0.023)$ & $(0.016)$ & $(0.039)$ & & $(0.041)$ \\
\hline East Germany & $\begin{array}{l}-1.058^{* * *} \\
(0.161)\end{array}$ & $\begin{array}{l}-0.674^{* * *} \\
(0.099)\end{array}$ & $\begin{array}{l}-0.846^{* * *} \\
(0.250)\end{array}$ & $\begin{array}{l}-0.294 \\
(0.628)\end{array}$ & $\begin{array}{l}-0.839^{* * *} \\
(0.248)\end{array}$ \\
\hline Log household size & $\begin{array}{l}-0.355^{* * *} \\
(0.043)\end{array}$ & $\begin{array}{l}-0.250^{* * *} \\
(0.029)\end{array}$ & $\begin{array}{l}-0.306^{* * *} \\
(0.058)\end{array}$ & $\begin{array}{l}-0.238^{* * * *} \\
(0.074)\end{array}$ & $\begin{array}{l}-0.262^{* * *} \\
(0.069)\end{array}$ \\
\hline One child & $\begin{array}{l}0.166^{* * *} \\
(0.034)\end{array}$ & $\begin{array}{l}0.119^{* * *} \\
(0.023)\end{array}$ & $\begin{array}{l}0.163^{* * *} \\
(0.041)\end{array}$ & $\begin{array}{l}0.155^{* * *} \\
(0.047)\end{array}$ & $\begin{array}{l}0.163^{* * *} \\
(0.040)\end{array}$ \\
\hline Two children & $\begin{array}{l}0.223^{* * *} \\
(0.040)\end{array}$ & $\begin{array}{l}0.149^{* * *} \\
(0.027)\end{array}$ & $\begin{array}{l}0.210^{* * *} \\
(0.053)\end{array}$ & $\begin{array}{l}0.192^{* * *} \\
(0.066)\end{array}$ & $\begin{array}{l}0.215^{* * *} \\
(0.053)\end{array}$ \\
\hline Three or more children & $\begin{array}{l}0.282^{* * *} \\
(0.053)\end{array}$ & $\begin{array}{l}0.178^{* * *} \\
(0.036)\end{array}$ & $\begin{array}{l}0.246^{* * *} \\
(0.069)\end{array}$ & $\begin{array}{l}0.201^{* *} \\
(0.087)\end{array}$ & $\begin{array}{l}0.257^{* * *} \\
(0.069)\end{array}$ \\
\hline Separated & $\begin{array}{l}-0.539^{* * *} \\
(0.076)\end{array}$ & $\begin{array}{l}-0.350^{* * *} \\
(0.048)\end{array}$ & $\begin{array}{l}-0.462^{* * *} \\
(0.104)\end{array}$ & $\begin{array}{l}-0.400^{* * *} \\
(0.140)\end{array}$ & $\begin{array}{l}-0.460^{* * *} \\
(0.104)\end{array}$ \\
\hline Single & $\begin{array}{l}-0.115^{* * *} \\
(0.042)\end{array}$ & $\begin{array}{l}-0.088^{* * *} \\
(0.028)\end{array}$ & $\begin{array}{l}-0.137^{* *} \\
(0.062)\end{array}$ & $\begin{array}{l}-0.174^{*} \\
(0.103)\end{array}$ & $\begin{array}{l}-0.120^{*} \\
(0.063)\end{array}$ \\
\hline Divorced & $\begin{array}{l}-0.433^{* * *} \\
(0.053)\end{array}$ & $\begin{array}{l}-0.286^{* * *} \\
(0.033)\end{array}$ & $\begin{array}{l}-0.398^{* * *} \\
(0.078)\end{array}$ & $\begin{array}{l}-0.342^{* * *} \\
(0.123)\end{array}$ & $\begin{array}{l}-0.388^{* * *} \\
(0.077)\end{array}$ \\
\hline Widowed & $\begin{array}{l}-0.426^{* * *} \\
(0.082)\end{array}$ & $\begin{array}{l}-0.276^{* * *} \\
(0.052)\end{array}$ & $\begin{array}{l}-0.438^{* * *} \\
(0.128)\end{array}$ & $\begin{array}{l}-0.329 \\
(0.210)\end{array}$ & $\begin{array}{l}-0.411^{* * *} \\
(0.129)\end{array}$ \\
\hline Spouse in native country & $\begin{array}{l}-0.812^{* * *} \\
(0.161)\end{array}$ & $\begin{array}{l}-0.540^{* * *} \\
(0.100)\end{array}$ & $\begin{array}{l}-0.584^{* *} \\
(0.272)\end{array}$ & $\begin{array}{r}0.957 \\
(0.588)\end{array}$ & $\begin{array}{l}-0.488^{*} \\
(0.267)\end{array}$ \\
\hline Very good & $\begin{array}{l}1.050^{* * *} \\
(0.346)\end{array}$ & $\begin{array}{l}0.787^{* * *} \\
(0.227)\end{array}$ & $\begin{array}{l}0.705^{* * *} \\
(0.254)\end{array}$ & $\begin{array}{c}0.528^{* *} \\
(0.257)\end{array}$ & $\begin{array}{l}0.686^{* * *} \\
(0.258)\end{array}$ \\
\hline Good & $\begin{array}{r}0.512 \\
(0.345)\end{array}$ & $\begin{array}{r}0.348 \\
(0.226)\end{array}$ & $\begin{array}{r}0.306 \\
(0.253)\end{array}$ & $\begin{array}{r}0.214 \\
(0.255)\end{array}$ & $\begin{array}{r}0.289 \\
(0.256)\end{array}$ \\
\hline Satisfactory & $\begin{array}{l}-0.174 \\
(0.345)\end{array}$ & $\begin{array}{l}-0.136 \\
(0.226)\end{array}$ & $\begin{array}{r}-0.162 \\
(0.253)\end{array}$ & $\begin{array}{r}-0.149 \\
(0.255)\end{array}$ & $\begin{array}{r}-0.173 \\
(0.256)\end{array}$ \\
\hline Poor & $\begin{array}{l}-0.843^{* *} \\
(0.346)\end{array}$ & $\begin{array}{l}-0.544^{* *} \\
(0.226)\end{array}$ & $\begin{array}{l}-0.708^{* * *} \\
(0.255)\end{array}$ & $\begin{array}{l}-0.627^{* *} \\
(0.258)\end{array}$ & $\begin{array}{l}-0.716^{* * *} \\
(0.258)\end{array}$ \\
\hline Bad & $\begin{array}{l}-2.096^{* * *} \\
(0.352)\end{array}$ & $\begin{array}{l}-1.209^{* * *} \\
(0.230)\end{array}$ & $\begin{array}{l}-1.721^{* * *} \\
(0.262)\end{array}$ & $\begin{array}{l}-1.491^{* * *} \\
(0.267)\end{array}$ & $\begin{array}{l}-1.726^{* * *} \\
(0.266)\end{array}$ \\
\hline Not in labour force & $\begin{array}{r}0.046 \\
(0.074)\end{array}$ & $\begin{array}{r}0.022 \\
(0.049)\end{array}$ & $\begin{array}{r}0.059 \\
(0.073)\end{array}$ & $\begin{array}{r}0.064 \\
(0.077)\end{array}$ & $\begin{array}{r}0.047 \\
(0.073)\end{array}$ \\
\hline Retired & $\begin{array}{l}-0.132 \\
(0.212)\end{array}$ & $\begin{array}{l}-0.105 \\
(0.132)\end{array}$ & $\begin{array}{c}-0.114 \\
(0.188)\end{array}$ & $\begin{array}{c}-0.104 \\
(0.210)\end{array}$ & $\begin{array}{l}-0.117 \\
(0.189)\end{array}$ \\
\hline In school/training & $\begin{array}{r}0.136 \\
(0.107)\end{array}$ & $\begin{array}{r}0.063 \\
(0.074)\end{array}$ & $\begin{array}{r}0.125 \\
(0.114)\end{array}$ & $\begin{array}{r}0.088 \\
(0.128)\end{array}$ & $\begin{array}{r}0.103 \\
(0.114)\end{array}$ \\
\hline Unemployed & $\begin{array}{l}-0.437^{* * *} \\
(0.080)\end{array}$ & $\begin{array}{l}-0.297^{* * *} \\
(0.052)\end{array}$ & $\begin{array}{l}-0.299^{* * *} \\
(0.082)\end{array}$ & $\begin{array}{l}-0.250^{* * *} \\
(0.087)\end{array}$ & $\begin{array}{l}-0.309^{* * *} \\
(0.082)\end{array}$ \\
\hline Self-employed & $\begin{array}{l}-0.194^{* * *} \\
(0.053)\end{array}$ & $\begin{array}{l}-0.129^{* * *} \\
(0.035)\end{array}$ & $\begin{array}{r}-0.062 \\
(0.076)\end{array}$ & $\begin{array}{r}0.036 \\
(0.106)\end{array}$ & $\begin{array}{r}-0.092 \\
(0.076)\end{array}$ \\
\hline Log wage & $\begin{array}{c}0.009 * \\
(0.005)\end{array}$ & $\begin{array}{c}0.006^{* *} \\
(0.003)\end{array}$ & $\begin{array}{c}0.008^{*} \\
(0.005)\end{array}$ & $\begin{array}{r}0.007 \\
(0.005)\end{array}$ & $\begin{array}{c}0.008^{*} \\
(0.005)\end{array}$ \\
\hline Log working hours & $\begin{array}{c}0.035^{*} \\
(0.019)\end{array}$ & $\begin{array}{r}0.015 \\
(0.013)\end{array}$ & $\begin{array}{l}0.062^{* * *} \\
(0.019)\end{array}$ & $\begin{array}{l}0.075^{* * * *} \\
(0.021)\end{array}$ & $\begin{array}{c}0.065^{* * *} \\
(0.020)\end{array}$ \\
\hline Log household income & $\begin{array}{l}0.597^{* * *} \\
(0.033)\end{array}$ & $\begin{array}{l}0.387^{* * *} \\
(0.022)\end{array}$ & $\begin{array}{l}0.492^{* * *} \\
(0.044)\end{array}$ & $\begin{array}{l}0.375^{* * *} \\
(0.052)\end{array}$ & $\begin{array}{l}0.371^{* * *} \\
(0.051)\end{array}$ \\
\hline$R^{2}$ & 0.277 & 0.080 & 0.269 & 0.143 & 0.272 \\
\hline
\end{tabular}

Robust standard errors in parentheses. ${ }^{* * *}$ significant at $1 \% ;{ }^{* *}$ significant at $5 \% ;{ }^{*}$ significant at $10 \%$. OLS $=$ Ordinary least square; $\mathrm{OP}=$ Ordered probit; $\mathrm{RE}=$ Random-effects; $\mathrm{FE}=$ Fixed-effects; $\mathrm{QFE}=$ Quasi fixed-effects. All specifications include ROR indicators and year dummies. QFE includes also individual averages over time of age, log household size, years of education, log household income and log working hours. The $R^{2}$ for the OP specification refers to pseudo- $R^{2}$. 
Table A3: Immigration and SWB: Benchmark results - natives and immigrants

\begin{tabular}{|c|c|c|c|c|c|}
\hline & OLS & OP & $\overline{\mathrm{RE}}$ & $\overline{\mathrm{FE}}$ & $\overline{\mathrm{QFE}}$ \\
\hline Immigration rate & $\begin{array}{c}0.052^{* * *} \\
(0.013)\end{array}$ & $\begin{array}{c}0.039^{* * *} \\
(0.009)\end{array}$ & $\begin{array}{c}0.043^{\text {*** }} \\
(0.014)\end{array}$ & $\begin{array}{c}0.040^{\text {*** }} \\
(0.015)\end{array}$ & $\begin{array}{c}0.049^{* * *} \\
(0.014)\end{array}$ \\
\hline Age & $\begin{array}{l}-0.085^{* * *} \\
(0.003)\end{array}$ & $\begin{array}{l}-0.057^{* * *} \\
(0.002)\end{array}$ & $\begin{array}{l}-0.077^{* * *} \\
(0.004)\end{array}$ & $\begin{array}{l}-0.038^{* * *} \\
(0.007)\end{array}$ & $\begin{array}{l}-0.185^{* * *} \\
(0.006)\end{array}$ \\
\hline Age squared & $\begin{array}{l}0.001^{* * *} \\
(0.000)\end{array}$ & $\begin{array}{l}0.001^{* * *} \\
(0.000)\end{array}$ & $\begin{array}{l}0.001^{* * *} \\
(0.000)\end{array}$ & $\begin{array}{l}0.001^{* * *} \\
(0.000)\end{array}$ & $\begin{array}{l}0.001^{* * *} \\
(0.000)\end{array}$ \\
\hline Female & $\begin{array}{l}0.127^{* * *} \\
(0.008)\end{array}$ & $\begin{array}{l}0.089^{* * *} \\
(0.006)\end{array}$ & $\begin{array}{l}0.147^{* * *} \\
(0.014)\end{array}$ & & $\begin{array}{l}0.124^{* * *} \\
(0.014)\end{array}$ \\
\hline East Germany & $\begin{array}{l}-0.349^{* * *} \\
(0.026)\end{array}$ & $\begin{array}{l}-0.241^{* * *} \\
(0.017)\end{array}$ & $\begin{array}{l}-0.409^{* * *} \\
(0.032)\end{array}$ & $\begin{array}{l}-0.205^{* * *} \\
(0.064)\end{array}$ & $\begin{array}{l}-0.354^{* * *} \\
(0.031)\end{array}$ \\
\hline Years of education & $\begin{array}{l}0.011^{* * *} \\
(0.002)\end{array}$ & $\begin{array}{l}0.008^{* * *} \\
(0.001)\end{array}$ & $\begin{array}{l}0.026^{* * *} \\
(0.003)\end{array}$ & $\begin{array}{r}0.004 \\
(0.006)\end{array}$ & $\begin{array}{c}0.013^{* *} \\
(0.006)\end{array}$ \\
\hline Log household size & $\begin{array}{l}-0.364^{* * *} \\
(0.015)\end{array}$ & $\begin{array}{l}-0.250^{* * *} \\
(0.010)\end{array}$ & $\begin{array}{l}-0.251^{* * *} \\
(0.019)\end{array}$ & $\begin{array}{l}-0.180^{* * *} \\
(0.024)\end{array}$ & $\begin{array}{l}-0.185^{* * *} \\
(0.023)\end{array}$ \\
\hline One child & $\begin{array}{l}0.102^{* * *} \\
(0.012)\end{array}$ & $\begin{array}{l}0.068^{* * *} \\
(0.008)\end{array}$ & $\begin{array}{l}0.104^{* * *} \\
(0.014)\end{array}$ & $\begin{array}{l}0.119^{* * *} \\
(0.017)\end{array}$ & $\begin{array}{l}0.108^{* * *} \\
(0.014)\end{array}$ \\
\hline Two children & $\begin{array}{c}0.197^{* * *} \\
(0.015)\end{array}$ & $\begin{array}{l}0.127^{* * *} \\
(0.010)\end{array}$ & $\begin{array}{c}0.168^{* * *} \\
(0.019)\end{array}$ & $\begin{array}{c}0.168^{* * * *} \\
(0.024)\end{array}$ & $\begin{array}{l}0.179^{* * *} \\
(0.019)\end{array}$ \\
\hline Three or more children & $\begin{array}{l}0.248^{* * *} \\
(0.022)\end{array}$ & $\begin{array}{l}0.170^{* * *} \\
(0.015)\end{array}$ & $\begin{array}{l}0.185^{* * *} \\
(0.030)\end{array}$ & $\begin{array}{l}0.187^{* * *} \\
(0.038)\end{array}$ & $\begin{array}{l}0.204^{* * *} \\
(0.030)\end{array}$ \\
\hline Single & $\begin{array}{l}-0.574^{* * *} \\
(0.031)\end{array}$ & $\begin{array}{l}-0.361^{* * *} \\
(0.020)\end{array}$ & $\begin{array}{l}-0.434^{* * *} \\
(0.037)\end{array}$ & $\begin{array}{l}-0.308^{* * *} \\
(0.044)\end{array}$ & $\begin{array}{l}-0.432^{* * *} \\
(0.037)\end{array}$ \\
\hline Separated & $\begin{array}{l}-0.261^{* * *} \\
(0.014)\end{array}$ & $\begin{array}{l}-0.181^{* * *} \\
(0.009)\end{array}$ & $\begin{array}{l}-0.213^{* * *} \\
(0.020)\end{array}$ & $\begin{array}{l}-0.164^{* * *} \\
(0.030)\end{array}$ & $\begin{array}{l}-0.206^{* * *} \\
(0.021)\end{array}$ \\
\hline Divorced & $\begin{array}{l}-0.320^{* * *} \\
(0.017)\end{array}$ & $\begin{array}{l}-0.208^{* * *} \\
(0.011)\end{array}$ & $\begin{array}{l}-0.226^{* * *} \\
(0.025)\end{array}$ & $\begin{array}{l}-0.022 \\
(0.039)\end{array}$ & $\begin{array}{l}-0.209^{* * *} \\
(0.025)\end{array}$ \\
\hline Widowed & $\begin{array}{l}-0.303^{* * *} \\
(0.029)\end{array}$ & $\begin{array}{l}-0.196^{* * *} \\
(0.020)\end{array}$ & $\begin{array}{l}-0.344^{* * *} \\
(0.049)\end{array}$ & $\begin{array}{l}-0.508^{* * *} \\
(0.089)\end{array}$ & $\begin{array}{l}-0.325^{* * *} \\
(0.049)\end{array}$ \\
\hline ative country & $\begin{array}{l}-0.655^{* * *} \\
(0.140)\end{array}$ & $\begin{array}{l}-0.462^{* * *} \\
(0.087)\end{array}$ & $\begin{array}{l}-0.491^{* *} \\
(0.223)\end{array}$ & $\begin{array}{r}0.664 \\
(0.446)\end{array}$ & $\begin{array}{l}-0.319 \\
(0.215)\end{array}$ \\
\hline Very good & $\begin{array}{l}1.074^{* * *} \\
(0.126)\end{array}$ & $\begin{array}{l}0.824^{* * *} \\
(0.084)\end{array}$ & $\begin{array}{c}0.766^{* * *} \\
(0.114)\end{array}$ & $\begin{array}{l}0.569^{* * *} \\
(0.118)\end{array}$ & $\begin{array}{l}0.753^{* * *} \\
(0.115)\end{array}$ \\
\hline Good & $\begin{array}{l}0.502^{* * *} \\
(0.126)\end{array}$ & $\begin{array}{l}0.328^{* * *} \\
(0.083)\end{array}$ & $\begin{array}{l}0.352^{* * *} \\
(0.114)\end{array}$ & $\begin{array}{l}0.258^{* *} \\
(0.117)\end{array}$ & $\begin{array}{l}0.347^{* * *} \\
(0.114)\end{array}$ \\
\hline Satisfactory & $\begin{array}{l}-0.252^{* *} \\
(0.126)\end{array}$ & $\begin{array}{l}-0.208^{* *} \\
(0.083)\end{array}$ & $\begin{array}{l}-0.173 \\
(0.114)\end{array}$ & $\begin{array}{l}-0.144 \\
(0.118)\end{array}$ & $\begin{array}{l}-0.170 \\
(0.114)\end{array}$ \\
\hline Poor & $\begin{array}{l}-1.021^{* * *} \\
(0.126)\end{array}$ & $\begin{array}{l}-0.671^{* * *} \\
(0.084)\end{array}$ & $\begin{array}{l}-0.792^{* * *} \\
(0.115)\end{array}$ & $\begin{array}{l}-0.663^{* * *} \\
(0.118)\end{array}$ & $\begin{array}{l}-0.784^{* * *} \\
(0.115)\end{array}$ \\
\hline Bad & $\begin{array}{l}-2.305^{* * *} \\
(0.131)\end{array}$ & $\begin{array}{l}-1.332^{* * *} \\
(0.086)\end{array}$ & $\begin{array}{l}-1.853^{* * *} \\
(0.121)\end{array}$ & $\begin{array}{l}-1.567^{* * *} \\
(0.125)\end{array}$ & $\begin{array}{l}-1.839^{* * *} \\
(0.121)\end{array}$ \\
\hline Not in labour force & $\begin{array}{r}0.006 \\
(0.026)\end{array}$ & $\begin{array}{l}-0.000 \\
(0.017)\end{array}$ & $\begin{array}{l}-0.001 \\
(0.024)\end{array}$ & $\begin{array}{r}-0.010 \\
(0.026)\end{array}$ & $\begin{array}{l}-0.010 \\
(0.024)\end{array}$ \\
\hline Retired & $\begin{array}{l}-0.053 \\
(0.066)\end{array}$ & $\begin{array}{l}-0.046 \\
(0.045)\end{array}$ & $\begin{array}{l}-0.045 \\
(0.059)\end{array}$ & $\begin{array}{l}-0.067 \\
(0.067)\end{array}$ & $\begin{array}{l}-0.046 \\
(0.059)\end{array}$ \\
\hline In school/training & $\begin{array}{l}0.116^{* * *} \\
(0.035)\end{array}$ & $\begin{array}{c}0.058^{* *} \\
(0.025)\end{array}$ & $\begin{array}{l}0.158^{* * *} \\
(0.035)\end{array}$ & $\begin{array}{l}0.101^{* * *} \\
(0.039)\end{array}$ & $\begin{array}{l}0.127^{* * *} \\
(0.035)\end{array}$ \\
\hline Unemployed & $\begin{array}{l}-0.667^{* * *} \\
(0.030)\end{array}$ & $\begin{array}{l}-0.411^{* * *} \\
(0.019)\end{array}$ & $\begin{array}{l}-0.502^{* * *} \\
(0.030)\end{array}$ & $\begin{array}{l}-0.439 * * * \\
(0.032)\end{array}$ & $\begin{array}{l}-0.504^{* * *} \\
(0.030)\end{array}$ \\
\hline Self-employed & $\begin{array}{l}-0.134^{* * *} \\
(0.016)\end{array}$ & $\begin{array}{l}-0.077^{* * *} \\
(0.011)\end{array}$ & $\begin{array}{l}-0.051^{* *} \\
(0.023)\end{array}$ & $\begin{array}{r}0.027 \\
(0.032)\end{array}$ & $\begin{array}{l}-0.063^{* * *} \\
(0.023)\end{array}$ \\
\hline Log wage & $\begin{array}{l}0.007^{* * *} \\
(0.002)\end{array}$ & $\begin{array}{l}0.004^{* * *} \\
(0.001)\end{array}$ & $\begin{array}{l}0.007^{* * *} \\
(0.002)\end{array}$ & $\begin{array}{c}0.004^{*} \\
(0.002)\end{array}$ & $\begin{array}{l}0.007^{* * *} \\
(0.002)\end{array}$ \\
\hline Log working hours & $\begin{array}{r}0.006 \\
(0.006)\end{array}$ & $\begin{array}{l}-0.004 \\
(0.004)\end{array}$ & $\begin{array}{l}0.026^{* * *} \\
(0.006)\end{array}$ & $\begin{array}{l}0.034^{* * *} \\
(0.007)\end{array}$ & $\begin{array}{l}0.031^{* * * *} \\
(0.006)\end{array}$ \\
\hline Log household income & $\begin{array}{l}0.599^{* * *} \\
(0.011)\end{array}$ & $\begin{array}{l}0.407^{* * *} \\
(0.008)\end{array}$ & $\begin{array}{l}0.468^{* * *} \\
(0.015)\end{array}$ & $\begin{array}{l}0.333^{* * *} \\
(0.018)\end{array}$ & $\begin{array}{l}0.320^{* * *} \\
(0.017)\end{array}$ \\
\hline$R^{2}$ & 0.273 & 0.081 & 0.268 & 0.231 & 0.273 \\
\hline
\end{tabular}

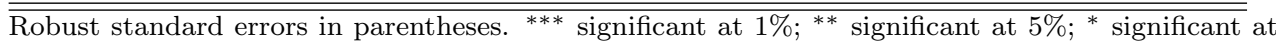
10\%. $\mathrm{OLS}=$ Ordinary least square; $\mathrm{OP}=$ Ordered probit; $\mathrm{RE}=$ Random-effects; $\mathrm{FE}=$ Fixed-effects; $\mathrm{QFE}=\mathrm{Quasi}$ fixed-effects. All specifications include ROR indicators and year dummies. QFE includes also individual averages over time of age, log household size, years of education, log household income and log working hours. The $R^{2}$ for the OP specification refers to pseudo- $R^{2}$. 